\title{
Variability and evolution of the midlatitude stratospheric aerosol budget from 22 years of ground-based lidar and satellite observations
}

\author{
Sergey M. Khaykin ${ }^{1}$, Sophie Godin-Beekmann ${ }^{1}$, Philippe Keckhut ${ }^{1}$, Alain Hauchecorne ${ }^{1}$, Julien Jumelet ${ }^{1}$, \\ Jean-Paul Vernier ${ }^{2,3}$, Adam Bourassa ${ }^{4}$, Doug A. Degenstein ${ }^{4}$, Landon A. Rieger ${ }^{4}$, Christine Bingen ${ }^{5}$, \\ Filip Vanhellemont ${ }^{5}$, Charles Robert $^{5}$, Matthew DeLand ${ }^{6}$, and Pawan K. Bhartia ${ }^{7}$ \\ ${ }^{1}$ LATMOS/IPSL, UVSQ Université Paris-Saclay, UPMC Univ. Paris 06, CNRS, \\ Guyancourt, France \\ ${ }^{2}$ Science Systems and Applications, Inc., Hampton, Virginia, USA \\ ${ }^{3}$ NASA Langley Research Center, Hampton, Virginia, USA \\ ${ }^{4}$ Institute of Space and Atmospheric Studies, University of Saskatchewan, \\ Saskatoon, Saskatchewan, Canada \\ ${ }^{5}$ Royal Belgian Institute for Space Aeronomy, Brussels, Belgium \\ ${ }^{6}$ Science Systems and Applications, Inc., Lanham, Maryland, USA \\ ${ }^{7}$ NASA Goddard Space Flight Center, Greenbelt, Maryland, USA \\ Correspondence to: Sergey M. Khaykin (sergey.khaykin@latmos.ipsl.fr)
}

Received: 23 September 2016 - Discussion started: 28 September 2016

Revised: 4 January 2017 - Accepted: 16 January 2017 - Published: 7 February 2017

\begin{abstract}
The article presents new high-quality continuous stratospheric aerosol observations spanning 1994-2015 at the French Observatoire de Haute-Provence (OHP, $44^{\circ} \mathrm{N}$, $\left.6^{\circ} \mathrm{E}\right)$ obtained by two independent, regularly maintained lidar systems operating within the Network for Detection of Atmospheric Composition Change (NDACC). Lidar series are compared with global-coverage observations by Stratospheric Aerosol and Gas Experiment (SAGE II), Global Ozone Monitoring by Occultation of Stars (GOMOS), Optical Spectrograph and InfraRed Imaging System (OSIRIS), Cloud-Aerosol Lidar with Orthogonal Polarization (CALIOP), and Ozone Mapping Profiling Suite (OMPS) satellite instruments, altogether covering the time span of OHP lidar measurements.

Local OHP and zonal-mean satellite series of stratospheric aerosol optical depth are in excellent agreement, allowing for accurate characterization of stratospheric aerosol evolution and variability at northern midlatitudes during the last 2 decades. The combination of local and global observations is used for a careful separation between volcanically perturbed and quiescent periods. While the volcanic signatures dominate the stratospheric aerosol record, the background aerosol
\end{abstract}

abundance is found to be modulated remotely by the poleward transport of convectively cleansed air from the deep tropics and aerosol-laden air from the Asian monsoon region. The annual cycle of background aerosol at midlatitudes, featuring a minimum during late spring and a maximum during late summer, correlates with that of water vapor from the Aura Microwave Limb Sounder (MLS).

Observations covering two volcanically quiescent periods over the last 2 decades provide an indication of a growth in the nonvolcanic component of stratospheric aerosol. A statistically significant factor of 2 increase in nonvolcanic aerosol since 1998, seasonally restricted to late summer and fall, is associated with the influence of the Asian monsoon and growing pollution therein.

\section{Introduction}

The role of the stratospheric aerosol burden in climate variability and ozone chemistry is well recognized. Long-term observations of stratospheric aerosol are essential for the in- 
terpretation of global atmospheric temperature and ozone layer variability (SPARC, 2006; Solomon et al., 2011). Regular vertically resolved observations of stratospheric aerosol began in the 1970s, 10 years after the pioneering in situ measurements by Junge et al. (1961) and remote detection by Fiocco and Grams (1964). Global information on stratospheric aerosol has been available since the late 1970s from various satellite missions, reviewed by SPARC (2006) and Kremser et al. (2016).

Volcanic eruptions with a Volcanic Explosivity Index (VEI) $\geq 4$ injecting sulfur into the stratosphere are a major source of stratospheric aerosol. In the absence of strong eruptions, the permanent stratospheric aerosol layer (also termed background aerosol) is commonly attributed to sulfuric gas precursors such as OCS and $\mathrm{SO}_{2}$ emitted at the surface and lofted into the stratosphere by deep convection and the Brewer-Dobson circulation. The removal of aerosols from the stratosphere occurs mainly by sedimentation and through the quasi-isentropic transport of air masses in tropopause folds (SPARC, 2006).

The long-term evolution of stratospheric aerosol has been a focus of several studies (see the review by Kremser et al., 2016, and references therein). Remote and in situ observations between the 1970s and 2004 did not reveal any significant change in the background aerosol (Deshler et al., 2006). Several further studies (Hoffmann et al., 2009; Vernier et al., 2011a; Trickl et al., 2013) reported an increase in stratospheric aerosol levels since 2002, but the source of this increase has been debated. Initially this increase was attributed by Hoffmann et al. (2009) to a rapid rise in Asian sulfur emissions, uplifted by deep convection within the Asian monsoon. Vernier et al. (2011a) used global satellite observations to demonstrate that the increase was primarily caused by moderate volcanic eruptions with VEI 4, whose impact should be carefully accounted for when analyzing the change in aerosol load. Although of much smaller significance compared to Pinatubo or El Chichón, these minor eruptions had a notable effect on climate (Solomon et al., 2011; Fyfe et al., 2013; Santer et al., 2014, 2015; Andersson et al., 2015), suggesting that even small variability in stratospheric aerosol matters.

It is now widely accepted that volcanic eruptions largely determine the observed variability in the stratospheric aerosol load (Kremser et al., 2016). Meanwhile, recent studies report a measurable increase in nonvolcanic components of aerosol within the Asian Tropopause Aerosol Layer (ATAL), occurring during the northern summer above the Asian monsoon (Vernier et al., 2015; Yu et al., 2015). Accurate long-term measurements are indispensable to quantify the human-induced change in stratospheric aerosol.

While measurements from space are performed with a large diversity of techniques, long-term ground-based observations are highly valuable as they ensure the continuity and coherence of the stratospheric aerosol record. During volcanically quiescent conditions, the accurate detection of stratospheric aerosols becomes challenging as the aerosol scattering signal becomes small compared to the molecular scattering. In an effort to better characterize the evolution of the stratospheric aerosol load and its variability at northern midlatitudes during the post-Pinatubo era we utilize a continuous 22-year observation record from the Observatoire de Haute-Provence and a variety of satellite data sets.

The paper is organized as follows: Section 2 provides information on the Observatoire de Haute-Provence (OHP) lidars, aerosol retrieval and satellite data sets exploited. Section 3 compares the OHP lidar and satellite aerosol records. Section 4 provides examples of volcanic plume detections and distinguishes volcanically perturbed and quiescent periods. Section 5 describes the variability, annual cycle and long-term change in background aerosol. Section 6 discusses the proposed interpretation and concludes the paper.

\section{Instruments and data sets}

\subsection{Observatoire de Haute-Provence lidars}

The Observatoire de Haute-Provence (OHP) located in southern France $\left(43.9^{\circ} \mathrm{N}, 5.7^{\circ} \mathrm{E} ; 670 \mathrm{~m}\right.$ a.s.l. $)$ is one of the Alpine stations within the Network for Detection of Atmospheric Composition Change (NDACC). The site is characterized by a high rate of clear nights and offers an opportunity for frequent lidar observations.

For over 3 decades two independent lidar systems have been operated at the OHP station: a differential absorption lidar (DIAL) for stratospheric ozone (hereafter referred to as LiO3S) and a Rayleigh-Mie-Raman lidar for middleatmosphere temperature measurements (hereafter referred to as LTA). Both the LiO3S (Godin-Beekmann et al., 2003) and LTA (Hauchecorne et al., 1992) lidar systems have provided routine measurements since 1985 and 1979, respectively. After a technical upgrade of both lidars in 1994, the mean measurement rate was 10-12 acquisition nights per month.

The LTA system includes a separate telescope and detection channel for clouds and aerosol (Chazette et al., 1995; Keckhut et al., 2005; Hoareau et al., 2013). In contrast to the previous studies, we use for the first time the primary lowgain detection channel of the LTA system for stratospheric aerosol retrieval. This choice benefits from lesser measurement gaps thanks to a more regular maintenance and a better signal-to-noise ratio of the LTA low-gain channel, which is achieved thanks to the electronic range gating adjusted to $12 \mathrm{~km}$ altitude. This configuration reduces the signal-induced noise at mid-stratospheric levels whilst limiting the useful measurement range to altitudes above $14 \mathrm{~km}$.

The off-line channel of LiO3S lidar features an Nd:YAG laser frequency-tripled to $355 \mathrm{~nm}$, which operates at a $50 \mathrm{~Hz}$ pulse rate and $42 \mathrm{~mJ}$ pulse ${ }^{-1}$ energy. The total collective surface of its mosaic four-mirror telescope is $0.88 \mathrm{~m}^{2}$. The primary low-gain channel of LTA makes use of a frequency- 
doubled Nd:YAG laser emitting at $532 \mathrm{~nm}$ with a pulse rate of $50 \mathrm{~Hz}$ and $350 \mathrm{~mJ}$ pulse $\mathrm{e}^{-1}$ energy and a $0.03 \mathrm{~m}^{2}$ telescope. The maximum vertical resolution for both lidars amounts to $15 \mathrm{~m}$; however, the vertical profiles are usually reported at $150 \mathrm{~m}$ resolution.

\subsection{OHP lidars aerosol retrieval}

For retrieving vertical profiles of stratospheric aerosol we use LiO3S and LTA measurements spanning 1994 through 2015 with a total number of 3118 (LiO3S) and 2691 (LTA) nights of lidar acquisitions, lasting $3-5 \mathrm{~h}$ each. The retrieval is based on the Fernald-Klett inversion method (Fernald, 1984; Klett, 1985), which provides backscatter and extinction coefficients. The reference zero-aerosol altitude is set between 30 and $33 \mathrm{~km}$. The scattering ratio (SR) is computed as a ratio of total to molecular backscattering:

$\mathrm{SR}=\frac{\beta_{\text {aero }}+\beta_{\mathrm{mol}}}{\beta_{\mathrm{mol}}}$,

where $\beta_{\text {aero }}$ and $\beta_{\mathrm{mol}}$ are the aerosol and molecular backscatter coefficients at a given wavelength.

LiO3S $355 \mathrm{~nm}$ backscatter $\beta_{\text {aero }}$, extinction $\alpha_{\text {aero }}$ and scattering ratio data are converted to $532 \mathrm{~nm}$ using Eqs. (2), (3) and (5) as follows:

$\beta_{\text {aero }}^{\lambda 2}=\beta_{\text {aero }}^{\lambda 1} \times\left(\frac{\lambda_{2}}{\lambda_{1}}\right)^{\kappa b}$,

$\alpha_{\text {aero }}^{\lambda 2}=\alpha_{\text {aero }}^{\lambda 1} \times\left(\frac{\lambda_{2}}{\lambda_{1}}\right)^{\kappa e}$,

where $\lambda_{1}=355 \mathrm{~nm}, \lambda_{2}=532 \mathrm{~nm}$ and $\kappa b$ and $\kappa e$ are wavelength exponents (Ångström coefficients), respectively, for particle backscatter and extinction. Assuming molecular backscatter

$\beta_{\mathrm{mol}} \propto \lambda^{-4.09}$,

the wavelength conversion of scattering ratio can be performed:

$\mathrm{SR}_{\lambda 2}=1+\left(\mathrm{SR}_{\lambda 1}-1\right)\left(\frac{\lambda_{2}}{\lambda_{1}}\right)^{4.09+\kappa b}$.

The wavelength exponents for the $355-532 \mathrm{~nm}$ pair were adapted from Jäger and Deshler $(2002,2003)$ and set to $\kappa e=-1.6$ and $\kappa b=-1.3$ after the year 1997. Similarly, the extinction-to-backscatter (lidar) ratio is set to $50 \mathrm{sr}$ after 1997, which is a commonly assumed value for volcanically quiescent conditions and periods of moderate eruptions (e.g., Trickl et al., 2013; Ridley et al., 2014; Sakai et al., 2016). The molecular backscatter is calculated from the National Centers for Environmental Prediction (NCEP) daily meteorological data interpolated to the OHP location. The lidar raw signals and resulting aerosol data have been subjected to a thorough quality screening, accounting for the instruments' technical health log. The overall rejection rate amounted to 17 and $12 \%$ for LiO3S and LTA, respectively.

Cumulative uncertainties of the backscatter measurements induced by random detection processes, the possible presence of aerosol at the reference altitude and the error in lidar ratio value do not exceed $7 \%$ as reported by Chazette et al. (1995). Another major source of uncertainty is the molecular number density derived from atmospheric pressure and temperature. The lidar inversion is particularly sensitive to the molecular density at the reference altitude, where the lidar return is assumed to be purely due to molecular scattering. Since the routine radiosonde measurements, commonly used to derive the molecular density, rarely reach reference altitudes above $30 \mathrm{~km}$, reanalysis data are required for the inversion.

We compared the monthly mean series of integrated backscatter coefficients in the $17-30 \mathrm{~km}$ layer retrieved using NCEP and ERA-Interim reanalyses and found a mean relative difference of $5.6 \%$ between both data sets. This value may serve as an estimate for the uncertainty due to molecular density. As a result, the total uncertainty of individual backscatter measurements is below $10 \%$. We note that the uncertainty in the assumed lidar ratio has a limited effect on the derived values of the backscatter coefficient and scattering ratio. For example, the sensitivity of the stratospheric mean $\beta_{\text {aero }}$ to the assumed lidar ratio was estimated to be $\sim 0.15 \% \mathrm{sr}^{-1}$ under background aerosol conditions (September 2005) and $\sim 0.23 \% \mathrm{sr}^{-1}$ under volcanically perturbed conditions (September 2011). Our estimates are compatible with those provided by Sakai et al. (2016). It should be noted that the error in the lidar ratio has a larger effect on aerosol extinction and optical depth, whose uncertainty may thus be somewhat larger.

\subsection{Satellite aerosol sounders}

Over the course of the last 2 decades stratospheric aerosol observations from space were conducted by various satellite missions, exploiting different measurement techniques: solar and stellar occultation and limb scattering as well as nadirviewing lidar. We use five satellite-based data sets, altogether covering the time span of OHP lidar observations.

SAGE II (Stratospheric Aerosol and Gas Experiment) (Russel and McCormick, 1989) is a seven-channel Sun photometer. It was launched onboard the Earth Radiation Budget Satellite in 1984 and provided solar occultation measurements of stratospheric aerosol extinction with a vertical resolution of $1 \mathrm{~km}$ until mid-2005. SAGE II fully covers the latitude range from $80^{\circ} \mathrm{S}$ to $80^{\circ} \mathrm{N}$ in 1 (Eq. 2) month with a typical rate of 32 measurements per day (reduced to 16 after 2000). We used SAGE II version 7.0 aerosol extinction data at $525 \mathrm{~nm}$.

GOMOS (Global Ozone Monitoring by Occultation of Stars) (Bertaux et al., 2010) is a UV-visible-near-infrared spectrometer launched in 2002 onboard ENVISAT and op- 
erated until April 2012. The instrument performed occultations of selected stars by means of four spectrometers. We use aerosol extinction profiles at $550 \mathrm{~nm}$ retrieved by the AerGOM algorithm, which was developed using an improved aerosol parameterization (Vanhellemont et al., 2016).

OSIRIS (Optical Spectrograph and InfraRed Imaging System) is a limb scatter instrument launched onboard the Odin satellite in 2001 and providing measurements of various chemical species and aerosol extinctions (McLinden et al., 2012). The primary instrument is an optical spectrograph (OS) operating in the $284-810 \mathrm{~nm}$ range and providing between 100 and 400 vertical profiles per day depending on the time of year. The principle of limb scattering and the Odin satellite orbit limit the coverage in the winter hemisphere in such a way that no data are available above $45^{\circ} \mathrm{N}$ during the 2-month period around the winter solstice. We use OSIRIS version 5.07 stratospheric aerosol extinction data at $750 \mathrm{~nm}$ (Bourassa et al., 2012a).

CALIOP (Cloud-Aerosol Lidar with Orthogonal Polarization) onboard the CALIPSO satellite platform is a nadirviewing active sounder (Winker et al., 2010). Operational since June 2006, CALIOP provides range-resolved measurements of elastic backscatter at 532 and $1064 \mathrm{~nm}$, with a vertical resolution of around $200 \mathrm{~m}$ in the stratosphere. CALIOP lidar makes use of an Nd:Yag laser operating at $20.2 \mathrm{~Hz}$ with a $110 \mathrm{~mJ}$ pulse $\mathrm{e}^{-1}$ power and a $0.78 \mathrm{~m}^{2}$ telescope. The data used here are based on nighttime $532 \mathrm{~nm}$ level $1 \mathrm{~B}$ version 4.00 product, post-processed using a treatment described by Vernier et al. (2009). The total attenuated backscatter profiles from CALIOP are corrected for molecular attenuation and ozone absorption after adjusting the calibration altitude to $36-39 \mathrm{~km}$. The attenuation by aerosol, constituting less than $1 \%$ at $15 \mathrm{~km}$ during background aerosol conditions, is neglected. Data below clouds are removed from the analysis. The scattering ratio profiles are obtained using molecular backscatter computed using NASA Global Modeling and Assimilation Office (GMAO) data. The backscatter data of CALIOP are cloud-cleared in the upper troposphere using a depolarization ratio threshold of $5 \%$. The conversion of backscatter to extinction is done using a lidar ratio of $50 \mathrm{sr}$.

OMPS (Ozone Mapping Profiling Suite) LP (Limb Profiler) onboard the Suomi NPP (National Polar-orbiting Partnership) satellite, launched in 2012, measures limb-scattered light with a sampling rate of up to 7000 measurements per day (Jaross et al., 2014). Regular observations of aerosol extinction have been available since April 2012. We use OMPS V0.5 extinction data at $675 \mathrm{~nm}$ (DeLand et al., 2016).

It should be noted that among the passive satellite sounders, SAGE II and GOMOS measure aerosol extinction, whereas OSIRIS and OMPS measure limb-scattered radiation, from which aerosol extinction is then retrieved. In contrast, the CALIOP instrument, based on an active sounding technique, measures aerosol backscatter. In order to compare OHP lidars and satellite instruments, all data sets were converted to extinction at a common wavelength of $532 \mathrm{~nm}$. Ta- ble 1 summarizes the wavelength exponents $\kappa e$ used for conversion (Eq. 3) and the time spans of data sets involved in the present analysis.

\section{Intercomparison of OHP lidars and satellite sounders}

Figure 1 shows time series of monthly averaged stratospheric aerosol optical depth between 17 and $30 \mathrm{~km}$ altitude $\left(\mathrm{sAOD}_{1730}\right)$ derived from OHP lidars and satellite data sets. Monthly mean values comprise on average $9(\mathrm{LiO} 3 \mathrm{~S})$ and 11 (LTA) individual acquisition nights (after quality screening), whereas the satellite values (monthly and zonally averaged over a $10^{\circ}$ latitude belt centered at OHP latitude) contain 72 (SAGE II), 128 (GOMOS), 97 (OSIRIS), $\sim 4 \times 10^{6}$ (CALIOP) and $\sim 3 \times 10^{3}$ (OMPS) individual measurements. The average standard error for monthly averages of OHP lidars' sAOD 1730 amounts to $4.8 \%$ (LiO3S) and $3.5 \%$ (LTA). The agreement between all data sets is remarkable despite the large variety of measurement techniques. The results of the intercomparison are summarized in Table 2. Note that the differences reported are computed for different time periods, depending on the availability of the data of each instrument as specified in Table 1.

The OHP lidars agree to within $1.3 \pm 1.3 \%$ (mean relative difference and two standard errors, $2 \mathrm{SE}$ ) with a correlation coefficient of 0.95 . The LiO3S and LTA lidars compared to the satellite mean $\mathrm{SAOD}_{1730}$ show a difference of $-1.0 \pm 2.0 \%$ ( $2 \mathrm{SE})$ and $-1.6 \pm 1.3 \%$ ( $2 \mathrm{SE})$ with a correlation of 0.96 and 0.97 , respectively. The satellite-to-satellite intercomparison shows mean discrepancies below $8 \%$ and correlation above 0.8 for any satellite pair except SAGE IIGOMOS (with a temporal overlap of $\sim 3$ years) and OMPS, whose observation record length is less than 4 years and covers a period with small geophysical variability. Note that the discrepancies may partly be caused by the error in the assumed wavelength exponents and lidar ratio. Indeed, the largest lidar-satellite discrepancies are obtained for the satellite sounders operating at higher wavelengths, i.e., OSIRIS $(750 \mathrm{~nm})$ and OMPS $(675 \mathrm{~nm})$, whereas the best agreement $(-0.4 \pm 1.7 \%)$ is between the OHP LTA lidar and CALIOP, both operating at $532 \mathrm{~nm}$.

Overall, all the biases are well below the statistical errors, which confirms the coherence between the continuous OHP record and the combined satellite time series. Note that the satellite series are zonally averaged over a $10^{\circ}$ latitude belt centered at OHP latitude in order to increase the sampling. The coherence between lidar and satellite series suggests that the stratospheric aerosol burden is zonally uniform at least on a monthly mean scale. This can be explained by the presence of strong zonal winds in the stratosphere, which rapidly homogenize the aerosol and tracers in the zonal direction. 


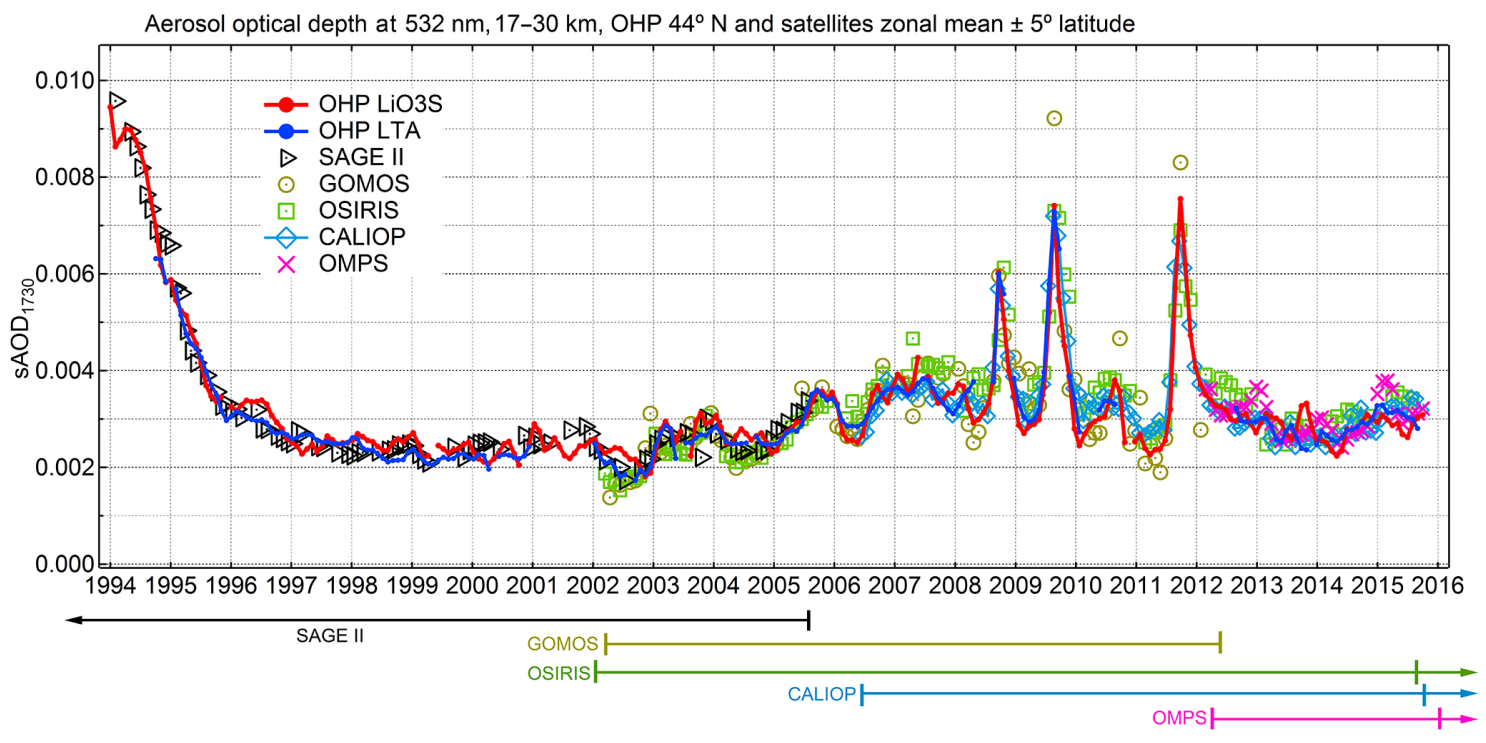

Figure 1. Time series of monthly mean sAOD 1730 from $\mathrm{OHP}$ lidars and monthly and zonal mean $\mathrm{sAOD}_{1730}$ within $40-50^{\circ} \mathrm{N}$ from satellite sounders. Time spans and data availability of satellite missions are shown below the panel (see Table 1 for additional information).

Table 1. Stratospheric aerosol sensors exploited (columns, left to right): name of instrument, operating wavelength, wavelength exponent for extinction $\kappa e$ used for conversion to $532 \mathrm{~nm}$, conversion factor (see Eq. 3), time span of available data.

\begin{tabular}{lrrrr}
\hline Instrument & Wavelength, $\lambda_{1}$ & W. exponent, $\kappa e$ & Factor $\left(\lambda_{2} / \lambda_{1}\right)^{\kappa e}$ & Time span, mm/yyyy \\
\hline OHP LiO3S & $355 \mathrm{~nm}$ & -1.6 & 0.524 & $01 / 1994-10 / 2015$ \\
OHP LTA & $532 \mathrm{~nm}$ & - & - & $10 / 1994-08 / 2015$ \\
SAGE II & $525 \mathrm{~nm}$ & -1.6 & 0.979 & $01 / 1994-08 / 2005$ \\
GOMOS & $550 \mathrm{~nm}$ & -1.6 & 1.055 & $04 / 2002-01 / 2012$ \\
OSIRIS & $750 \mathrm{~nm}$ & -2.0 & 1.988 & $02 / 2002-07 / 2015$ \\
CALIOP & $532 \mathrm{~nm}$ & - & - & $06 / 2006-09 / 2015$ \\
OMPS & $675 \mathrm{~nm}$ & -1.8 & 1.535 & $04 / 2012-10 / 2015$ \\
\hline
\end{tabular}

The layer between 17 and $30 \mathrm{~km}$, for which the comparison is reported in Fig. 1 and Table 2, does not represent the total stratospheric aerosol column. A significant fraction of stratospheric aerosol resides below $17 \mathrm{~km}$ (Ridley et al., 2014; Andersson et al., 2015); however, an accurate detection of the aerosol abundance in the lowermost stratosphere is more challenging for limb-viewing satellite instruments (Bourassa et al., 2010; Thomason and Vernier, 2013), which may lead to larger discrepancies in SAOD.

Figure 2 displays a comparison of aerosol extinction profiles averaged over two 20-month periods in 2002-2003 and 2013-2014 covered by time-overlapping observations by two different triplets of satellite sounders. These periods are also characterized by a stable aerosol load that is without strong enhancements due to volcanic eruption. The comparison reveals close agreement between the OHP lidar, SAGE II, GOMOS and OSIRIS (Fig. 2a) above $15 \mathrm{~km}$ and somewhat poorer agreement below. Figure $2 \mathrm{~b}$ suggests a good agreement between the OHP lidar and CALIOP (relative difference $5-10 \%$ ) throughout the entire range of altitudes except the uppermost layer above $25 \mathrm{~km}$, where the OHP lidar is 15-20\% lower than CALIOP. This feature may be related to an error in lidar calibration, relying on the assumption of the absence of aerosol above $30 \mathrm{~km}$, which - as suggested by CALIOP data calibrated at higher altitudes - may not always be the case. The other two satellite sounders covering the 2013-2014 period - OSIRIS and OMPS - show somewhat larger discrepancies with the OHP lidar and CALIOP, reaching $30 \%$ in the uppermost and lowermost layers. This discrepancy may be due to the use of the fixed wavelength exponents, which may vary with height depending on the size distribution of aerosol.

\section{Volcanic plumes and quiescent periods}

The remarkable coherence between the lidar- and satellitebased $\mathrm{SAOD}_{1730}$ series demonstrated in the previous section allows for a synergetic use of local and global observations to characterize the variability in stratospheric aerosol in the best 
Table 2. Intercomparison of stratospheric aerosol optical depth between 17 and $30 \mathrm{~km}\left(\mathrm{sAOD}_{1730}\right)$ series displayed in Fig. 1. Mean relative difference $\Delta_{\text {mean }} \pm 2$ standard errors (top) and correlation coefficient $R$ (bottom). The relative difference in the top panel is calculated as $100 \%\left(X_{\text {row }}-X_{\text {column }}\right) / \overline{\left(X_{\text {row }}+X_{\text {column }}\right)}$, where $X$ is the sAOD 1730 value averaged over the entire observation time span of the respective instrument (see Table 1) or the mean of all satellite instruments (last column).

\begin{tabular}{lrrrrrrr}
\hline$\Delta_{\text {mean }} \pm$ 2SE, \% & LTA & SAGE II & GOMOS & OSIRIS & CALIOP & OMPS & Sat_mean \\
\hline LiO3S & $1.3 \pm 1.3$ & $1.4 \pm 2.3$ & $3.9 \pm 4.2$ & $-3.3 \pm 3.1$ & $-2.0 \pm 2.3$ & $-4.4 \pm 3.6$ & $-1.0 \pm 2.0$ \\
LTA & & $-1.9 \pm 1.8$ & $1.7 \pm 3.7$ & $-2.5 \pm 2.5$ & $-0.4 \pm 1.7$ & $-4.3 \pm 2.8$ & $-1.7 \pm 1.3$ \\
SAGE II & & & $-0.1 \pm 5.9$ & $7.7 \pm 6.0$ & - & - & $2.1 \pm 2.7$ \\
GOMOS & & & & $-5.8 \pm 3.4$ & $-1.6 \pm 3.7$ & - & $-1.9 \pm 1.9$ \\
OSIRIS & & & & & $7.7 \pm 2.1$ & $6.6 \pm 4.0$ & $3.2 \pm 1.3$ \\
CALIOP & & & & & & $-5.5 \pm 2.7$ & $-3.1 \pm 1.2$ \\
\hline R correl & LTA & SAGE II & GOMOS & OSIRIS & CALIOP & OMPS & Sat_mean \\
\hline LiO3S & 0.95 & 0.98 & 0.9 & 0.86 & 0.91 & 0.62 & 0.96 \\
LTA & & 0.98 & 0.9 & 0.91 & 0.96 & 0.72 & 0.97 \\
SAGE II & & & 0.7 & 0.85 & - & - & \\
GOMOS & & & & 0.86 & 0.88 & - & \\
OSIRIS & & & & & 0.93 & 0.65 & \\
CALIOP & & & & & & & \\
\hline
\end{tabular}
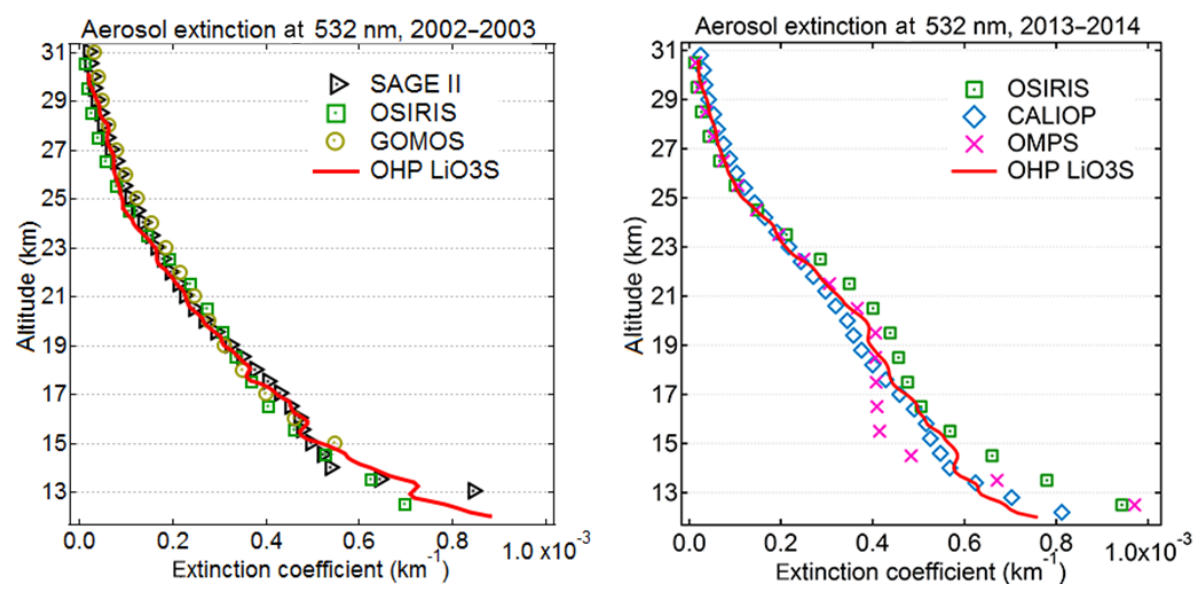

Figure 2. Comparison of aerosol extinction profiles at $532 \mathrm{~nm}$ from OHP lidars and satellites averaged over volcanically quiescent periods 2002-2003 (left) and 2013-2014 (right).

way. Figure 3 shows sAOD 1730 series computed by averaging the OHP lidars and all five satellites data sets. The timing of VEI 4 volcanic eruptions north of $20^{\circ} \mathrm{S}$ is indicated by vertical arrows, whereas the periods affected by these eruptions are marked by light blue shading. The selection criteria are described hereinafter (Sect. 4.4), whereas the eruptions and periods affected are summarized in Table 3.

\subsection{Quiescent period 1997-2003}

The $\mathrm{sAOD}_{1730}$ series since 1994 shows a tail of Pinatubo aerosol followed by a stabilization at a quasi-constant level around mid-1997 according to SAGE II and OHP lidar observations. Between mid-1997 and late 2001 aerosol loading remains stable, with no discernible eruption-induced enhancements at Northern Hemisphere $(\mathrm{NH})$ midlatitudes. This is fully consistent with other midlatitude lidar observations (Deshler et al., 2006; Trickl et al., 2013; Sakai et al., 2016). Although some VEI 4 eruptions between 2000 and 2003 have occurred over that time, they had very limited stratospheric impact (Vernier et al., 2011a; Kremser et al., 2016). Examination of scattering ratio profiles from OHP lidars did not reveal any signatures of volcanic plumes at or above $17 \mathrm{~km}$ altitude.

Importantly, the stratospheric aerosol levels during the 1997-2003 period are at or below any previous background period since 1970 (Jäger, 2005; Deshler et al., 2006) and may thus be regarded as a reference level for background stratospheric aerosol against which further changes in aerosol load should be compared. According to the mean of OHP lidars, the average background sAOD 1730 for the "reference" quies- 


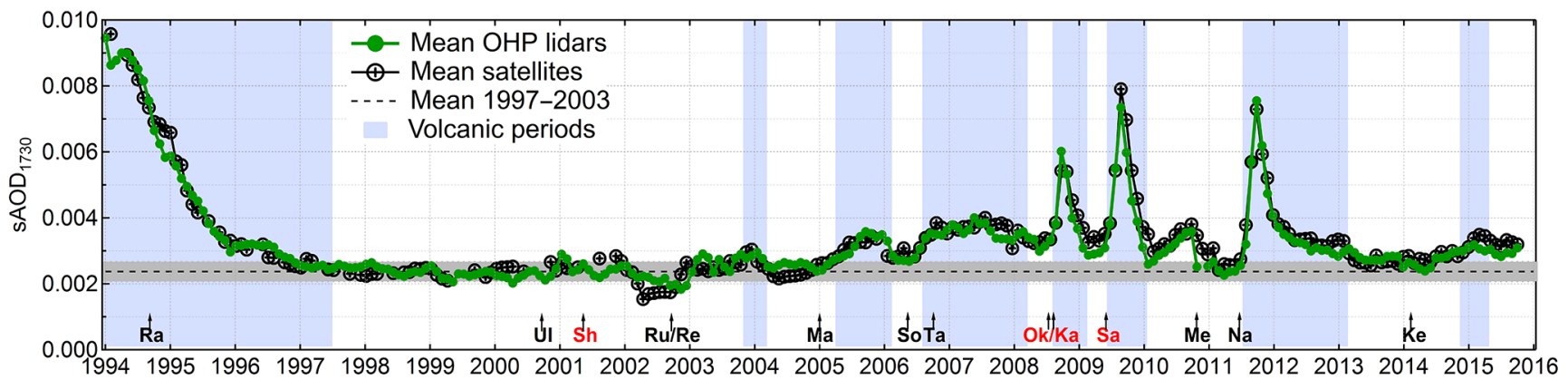

Figure 3. Time series of monthly mean $\mathrm{SAOD}_{1730}$ computed by averaging both OHP lidars and all satellites. VEI 4 eruptions $>20^{\circ} \mathrm{S}(\mathrm{Table} 3)$ are indicated along the $x$ axis, $\mathrm{NH}$ midlatitude eruptions are marked red. The horizontal dashed line and grey shading indicate the average value of $\mathrm{sAOD}_{1730}$ over the reference quiescent period and its $\pm 1-\sigma$ range of values, respectively $\left(2.37 \times 10^{-3} \pm 12.6 \%\right)$. Time periods considered as perturbed by volcanism are shaded light blue. See text for details.

Table 3. List of volcanic eruptions of VEI 4 occurring in the tropics and Northern Hemisphere ( $>20^{\circ}$ S) between 1994 and 2016 as reported by the Smithsonian Institution Global Volcanism Program (http://volcano.si.edu). The temporal extent of the volcanically perturbed period at OHP from the corresponding eruption is provided in the rightmost two columns.

\begin{tabular}{lrrrr}
\hline Volcano (VEI 4) & Eruption date & Latitude & Start of period & End of period \\
\hline Rabaul (Ra) & Sep 1994 & $4^{\circ} \mathrm{S}$ & Oct 1994 & Undefined \\
Ulawun (Ul) & Sep 2000 & $5^{\circ} \mathrm{S}$ & Undetected & Undetected \\
Shiveluch (Sh) & May 2001 & $56^{\circ} \mathrm{N}$ & Undetected & Undetected \\
Ruang (Ru) & Sep 2002 & $2^{\circ} \mathrm{N}$ & Nov 2003 & Feb 2004 \\
Reventador (Re) & Nov 2002 & $0^{\circ} \mathrm{N}$ & Nov 2003 & Feb 2004 \\
Manam (Ma) & Jan 2005 & $4^{\circ} \mathrm{S}$ & Apr 2005 & Feb 2006 \\
Soufrière Hills (So) & May 2006 & $16^{\circ} \mathrm{N}$ & Aug 2006 & Undefined \\
Tavurvur (Ta) & Oct 2006 & $4^{\circ} \mathrm{S}$ & Undefined & Feb 2008 \\
Okmok (Ok) & Jul 2008 & $55^{\circ} \mathrm{N}$ & Aug 2008 & Jan 2009 \\
Kasatochi (Ka) & Aug 2008 & $55^{\circ} \mathrm{N}$ & Aug 2008 & Jan 2009 \\
Sarychev (Sa) & Jun 2009 & $48^{\circ} \mathrm{N}$ & Jun 2009 & Dec 2009 \\
Merapi (Me) & Oct 2010 & $7^{\circ} \mathrm{S}$ & Undetected & Undetected \\
Nabro (Na) & Jun 2011 & $13^{\circ} \mathrm{N}$ & Jul 2011 & Feb 2013 \\
Kelud (Ke) & Feb 2014 & $8^{\circ} \mathrm{S}$ & Dec 2014 & Apr 2015 \\
\hline
\end{tabular}

cent period of $2.37 \times 10^{-3} \pm 12.6 \%(1 \sigma)$, which is marked in Fig. 3 by a dashed line and grey shading, indicating a $\pm 1-$ $\sigma$ range of values. SAGE II reports $\mathrm{SAOD}_{1730}$ for the same period of $2.4 \times 10^{-3} \pm 10.2 \%$.

\subsection{Volcanically active period 2003-2013}

The continuous quiescent period is terminated in late 2003, when the plume of the tropical Ruang and Reventador eruptions (Thomason et al., 2008) reaches NH midlatitudes. The subsequent VEI 4 eruptions of the Manam volcano at $4^{\circ} \mathrm{S}$ (Vanhellemont et al., 2010), Soufrière Hills at $16^{\circ} \mathrm{N}$ (Prata et al., 2007) and Tavurvur at $4^{\circ} \mathrm{S}$ lead to step-like increases in $\mathrm{sAOD}_{1730}$. In Summer 2008, two neighboring VEI 4 eruptions of the Okmok and Kasatochi volcanoes at $55^{\circ} \mathrm{N}$ (Bourassa et al., 2010) result in a rapid increase in $\mathrm{sAOD}_{1730}$ followed by a relaxation to quasi-background level with an e-folding time of 6 months.

\subsubsection{Detection of Sarychev and Nabro plumes}

In June 2009, the eruption of Sarychev at $48^{\circ} \mathrm{N}$ (Haywood et al., 2010) increases $\mathrm{SAOD}_{1730}$ to $7.5 \times 10^{-3}$ (mean of OHP lidars), the highest value since 1994 . The post-Sarychev recovery is relatively fast, with only $4-5$ months of e-folding period, after which $\mathrm{SAOD}_{1730}$ returns to background level in January-February 2010.

A strong enhancement of $\mathrm{sAOD}_{1730}$ follows the eruption of the Nabro volcano $\left(14^{\circ} \mathrm{N}\right)$ in June 2011. A rapid hemisphere-wide dispersion of the Nabro plume was facilitated by the Asian monsoon (Bourassa et al., 2012b; Fairlie et al., 2014), although the role of the monsoon in providing an alternative pathway for aerosol and/or $\mathrm{SO}_{2}$ into the stratosphere is debated (Vernier et al., 2013; Fairlie et al., 2014). Interestingly, the midlatitude Sarychev eruption and the tropical Nabro eruption resulted in an $\mathrm{sAOD}_{1730}$ enhancement of nearly the same amplitude; however, the re- 
moval of Nabro aerosol took a much longer time (e-folding period of up to 19 months) according to zonal-mean series derived from CALIOP and OSIRIS.

A better insight into the temporal evolution and vertical structure of Sarychev and Nabro plumes is provided by Fig. 4, showing scattering ratio (SR) profiles obtained by the OHP LiO3S lidar during the corresponding volcanic periods and converted to $532 \mathrm{~nm}$. The plume of Sarychev was detected at OHP 14 days after the eruption as sharp SR enhancements in the lowermost stratosphere reaching a maximum value of 4.8 at $15 \mathrm{~km}$ (30 June 2009). On 15 July 2009 a sharp enhancement with a peak SR of 2 was observed by LiO3S as high as $21.7 \mathrm{~km}$. The presence of aerosol at this level is confirmed by LTA observations on the next night (not shown), which reported SR at this level reaching a value of 3.5. A remarkable scatter between the individual profiles points to a rapid three-dimensional evolution of the plume (Jégou et al., 2013), dispersed by the stratospheric mean zonal flow, which reversed over the course of the plume permanence.

The first signatures of the Nabro plume were detected at OHP already 15 days after the eruption: a strong peak in SR reaching 2.8 was observed at $16.5 \mathrm{~km}$ on 28 June 2011 (Sawamura et al., 2012). Over the course of July, several relatively thin $(<1 \mathrm{~km})$ aerosol layers with an SR below 1.6 were detected between 14 and $17 \mathrm{~km}$ altitude. Starting from early August ( 50-60 days after eruption), the plume of Nabro - as observed at OHP - expands in altitude and obtains a smoother shape, indicating the arrival of air masses in which the aerosol-laden air is mixed with the ambient air by the general flow. Broad $(\sim 3 \mathrm{~km})$ enhancements with a peak SR of $\sim 1.5$ centered at $17 \mathrm{~km}$ were observed at OHP through March 2012.

\subsection{Post-Nabro period}

By early mid-2013 all data sets report sAOD ${ }_{1730}$ stabilizing around $2.8 \times 10^{-3} \pm 3.0 \%$ (mean lidars) or $2.8 \times 10^{-3} \pm 3.5 \%$ (mean satellites) and remaining at that level for almost 2 years, through December 2014. In January 2015, the plume of the Kelud eruption (Kristiansen et al., 2015) reached OHP latitude as inferred from CALIOP sAOD $_{1730}$ time-latitude section (not shown). The signatures of the Kelud plume were observed at OHP until April 2015, after which $\mathrm{SAOD}_{1730}$ returned to near background levels.

\subsection{Identification of volcanically perturbed periods}

Since 1994 the major perturbations of NH stratospheric aerosol load were caused by midlatitude volcanic eruptions of Okmok and Kasatochi and Sarychev as well as the tropical eruption of Nabro, all readily reflected in OHP lidars and satellite $\mathrm{sAOD}_{1730}$ series (Figs. 1 and 3). The plumes of more distant (tropical) eruptions are not always obvious in OHP observations. In order to accurately distinguish be- tween volcanically perturbed and quiescent periods, we use global-coverage satellite observations to track the spatiotemporal evolution of each volcanic plume.

Volcanic plumes were detected by examining timelatitude sections of $\mathrm{SAOD}_{1730}$ and $\mathrm{sAOD}_{1519}$ from all satellite records (example for CALIOP is provided hereinafter in Sect. 5). If a plume was found to extend beyond the tropical belt towards the northern extratropics, the OHP lidar monthly mean SAOD 1730 values and SR profiles posterior to the eruption were compared against those averaged over the reference quiescent period 1997-2003. This way, the presence of a plume at OHP and the temporal extent of the corresponding volcanic period were determined. In other words, the satellite data were used to detect a plume, whereas the OHP lidar data were used to determine the duration of the respective volcanic period at OHP latitude. Thus, a period is considered as volcanically perturbed if a plume occurs in the Northern Hemisphere and if both of the following two conditions are fulfilled in OHP observation posterior to the eruption:

i. monthly mean $\mathrm{sAOD}_{1730}$ value exceeds the $1-\sigma$ range of the reference quiescent period of 1997-2003 (grey band in Fig. 3);

ii. monthly mean SR profile exceeds the 1- $\sigma$ range of the "background" SR profile - an average over the entire reference quiescent period of 1997-2003 (grey-filled in Fig. 5) in a layer $>2 \mathrm{~km}$ thick.

Figure 5 shows the difference between averaged SR profiles for the quiescent and volcanically perturbed periods in order to clarify the application of the second selection criterion. The black solid curve and grey shading represent the mean SR profile for the reference period (1997-2003) and its $1-\sigma$ range, respectively. The colored curves show SR profiles corresponding to the aged plumes of tropical eruptions of Ruang, Nabro and Kelud. The maximum SR values of these profiles are remarkably smaller than those observed in a young plume (cf. Fig. 4); however, they are visibly beyond the grey-shaded background range of SR. The same consideration holds for the corresponding sAOD 1730 values in Fig. 3. This allows for the classification of the respective periods as volcanically perturbed. The timing of VEI 4 eruptions and the lifetime of their plumes as detected at OHP are listed in Table 3.

We noted that the time required for a plume to propagate to OHP latitude depends on the eruption season and injection altitude. In particular, the tropical eruptions injecting material directly into the lower stratosphere (e.g., Soufrière Hills or Kelud) would have a longer lifetime in the stratosphere; however, their poleward propagation is inhibited during boreal summer, when stratospheric meridional exchange weakens. For this reason, the Kelud plume has reached OHP latitude only about 10 months after the eruption. The period between the full decay of the Nabro plume in early 2013 and the arrival of the aged Kelud plume in late 2014 is character- 

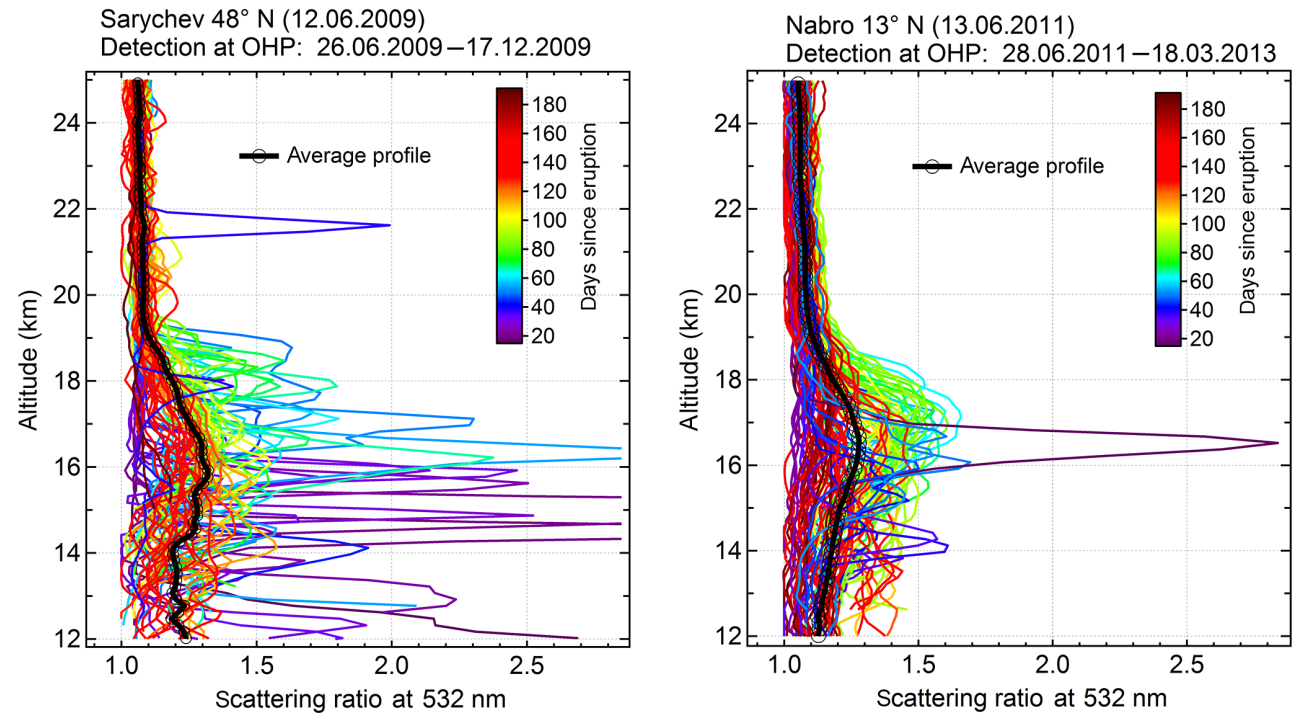

Figure 4. Individual (colored curves) and period-averaged (black circles) scattering ratio profiles from the OHP LiO3S lidar acquired after the eruptions of Sarychev (left) and Nabro (right) volcanoes. The colors of individual profiles denote the days since eruption. The eruption dates and plume detection periods are indicated in each panel. Only the data above the local tropopause (NCEP) are shown.

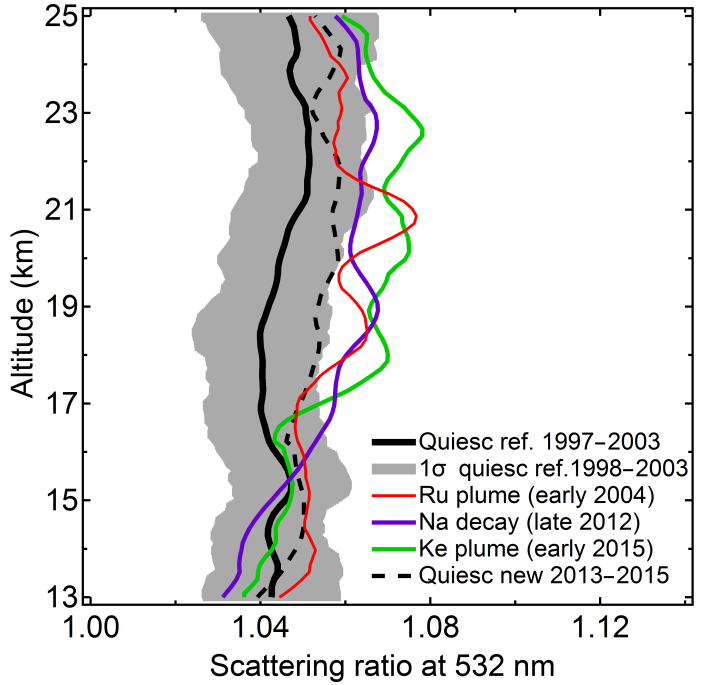

Figure 5. Vertical profiles of scattering ratio $(532 \mathrm{~nm})$ averaged over different periods: reference quiescent period (Quiesc. ref. 19972003) and its 1 standard deviation range ( $1 \sigma$ Quiesc. ref.); aged volcanic plumes of Ruang and Reventador (red); Nabro in late 2012 (violet); Kelud (green); post-Nabro quiescent period (Quiesc. new, black dashed). See Fig. 3 and Table 2 for details on period definition.

ized by an SR profile (dashed curve in Fig. 5) lying within the background range of values. The $\mathrm{SAOD}_{1730}$ is relatively stable and remains within the background range during this period, which is therefore classified as quiescent.

\section{Nonvolcanic drivers of aerosol variability}

Figure 6 displays the time-latitude section of zonal-mean AOD in a layer between 15 and $19 \mathrm{~km}\left(\mathrm{sAOD}_{1519)}\right)$ from CALIOP data and time series of the same quantity obtained by OHP LiO3S lidar. The $15-19 \mathrm{~km}$ layer is chosen because it is directly impacted by most of VEI 4 eruptions and is characterized by efficient quasi-isentropic exchange within the upper troposphere and lower stratosphere (UTLS) (e.g., Kremser et al., 2016). The enhanced poleward transport into the winter hemisphere is exhibited by meridional wind vectors in Fig. 6.

Beside the volcanic plumes, CALIOP observations reveal systematic enhancement in $\mathrm{AOD}_{1519}$ between about 15 and $45^{\circ} \mathrm{N}$ during the northern summer, with the most prominent ones occurring in 2007, 2010, 2013 and 2015. Given its timing and location, this feature can be attributed to the Asian Tropopause Aerosol Layer (ATAL) (Vernier et al., 2011b; Thomason and Vernier, 2013), occurring in the $15-18 \mathrm{~km}$ layer above the Asian summer monsoon and extending to midlatitudes (Vernier et al., 2015).

Another feature revealed by CALIOP is a systematic aerosol depletion in January-February around the equator and spreading poleward. The tongues of aerosol-poor air are readily discernible in 2007, 2008, 2010, 2012 and 2015 , whereas in the other years they are scrambled by volcanic plumes or hardly discernible from the low background aerosol burden. The timescale of the poleward transport of clean air can be inferred from the shape of the clean air tongues - fast within the tropical belt and slower across the subtropical stratospheric barrier. The systematic aerosol depletion in the TTL (tropical tropopause layer) during austral 


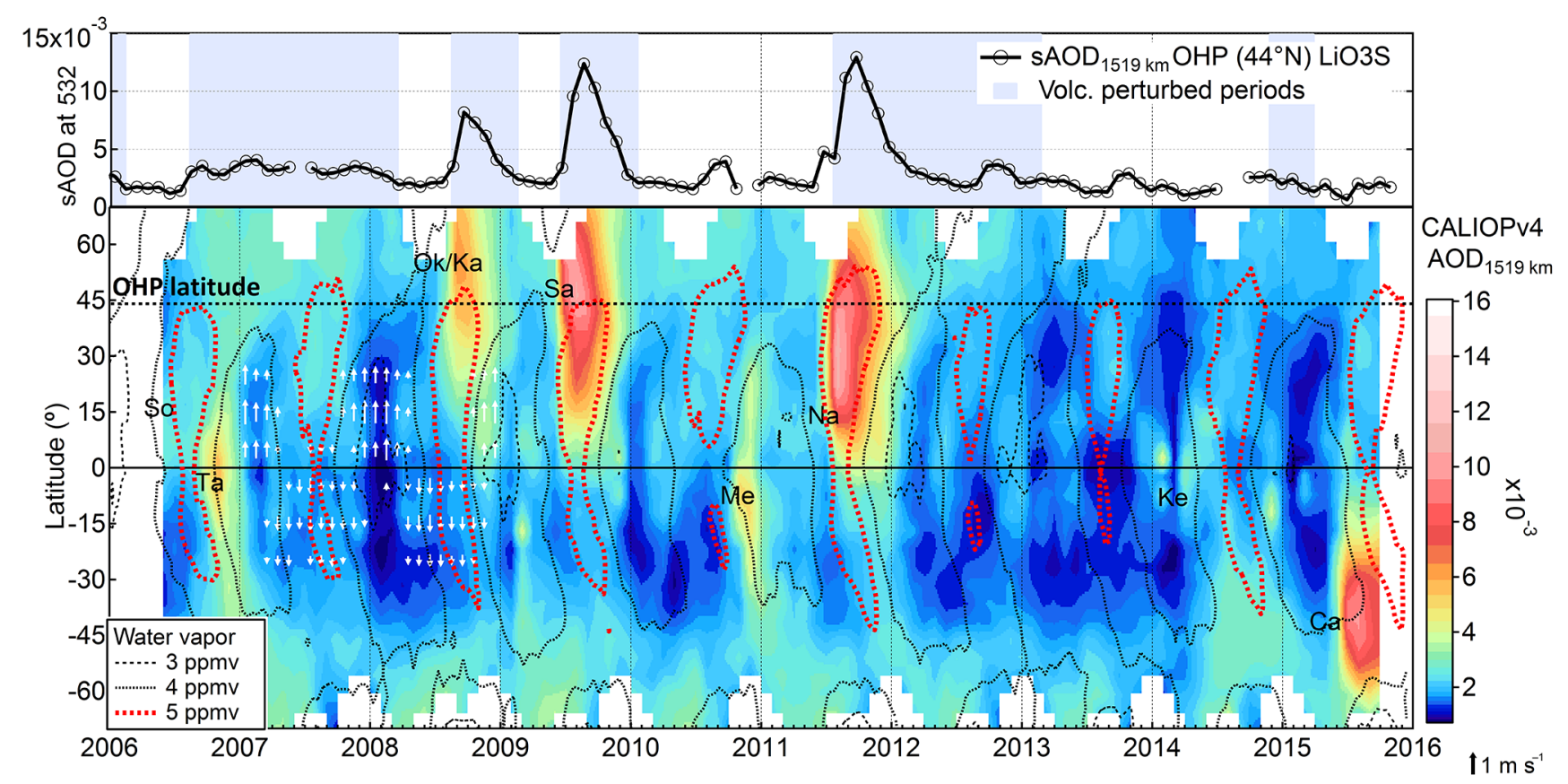

Figure 6. Time series of monthly mean $\mathrm{sAOD}_{1519}$ from OHP LiO3S lidar (top) and time-latitude section of zonal-mean $\mathrm{AOD}_{1519}$ from CALIOP in log-scaled color map with indications of VEI 4 eruptions (bottom). Time periods considered as perturbed by volcanism (Table 3 ) are shaded light blue in the top panel. White arrows (in 2007-2008) represent the mean meridional component of monthly and zonally averaged horizontal wind at $100 \mathrm{hPa}$ from ERA-Interim reanalysis. Dashed and dotted contours depict the zonal-mean water vapor mixing ratio at $100 \mathrm{hPa}$ from Aura MLS.

summer was attributed by Vernier et al. (2011c) to fast convective cross-tropopause transport (overshooting) of clean tropospheric air (cleansing). The clean air reaches OHP latitude in about 3 months, which is reflected in the OHP lidar series, showing a recurring minimum in late spring-early summer.

The time-latitude pattern of $\mathrm{SAOD}_{1519}$ can be paralleled with that of water vapor at $100 \mathrm{hPa}$ level from Aura Microwave Limb Spectrometer (MLS) (Waters et al., 2006) version 4.2 data (Livesey et al., 2015). Dashed and dotted contours in Fig. 6 encircle the areas of water vapor mixing ratio of 3, 4 and 5 ppmv. The 5 ppmv (red dashed) contour shows the area of the annual maximum of water emerging during the northern summer, which can be attributed to the moisture flux from the Asian monsoon (Park et al., 2007; Schwartz et al., 2015). The moist air is traceable to OHP latitude and coincides in time and space with the annual maximum of $\mathrm{sAOD}_{1519}$, associated with ATAL. Spatiotemporal match of the aerosol and water vapor annual maxima suggests the same origin of both - the Asian monsoon.

The areas of the annual minimum of water vapor (black dashed contours) correlate with the minima in TTL aerosol load, both occurring during the southern summer. While the annual minimum of water vapor can be readily explained by the coldest TTL temperatures in January-February leading to enhanced dehydration of the TTL (e.g., Holton et al., 1995), the aerosol reduction can be attributed to convective cleans- ing during austral summer (Vernier et al., 2011c). Both dry and clean air features show similar poleward propagation. Overall, the seasonal cycle of stratospheric aerosol loading in the TTL, featuring a maximum in NH during boreal summer and minimum around the equator during austral summer is similar to that of water vapor.

\subsection{Annual cycle}

Figure 7a shows a climatological annual cycle of scattering ratio (SR) profile from OHP LiO3S lidar based on the periods considered as volcanically quiescent (see Fig. 3). Throughout the seasons and altitude layers the SR does not exceed 1.07, meaning that for the quiescent conditions the aerosol backscatter constitutes less than $7 \%$ of the molecular backscatter. The permanent layer of aerosol in the stratosphere, also referred to as Junge layer (Junge et al., 1961), is commonly attributed to sulfuric gas precursors emitted at the surface and eventually transformed into an $\mathrm{H}_{2} \mathrm{SO}_{4}-\mathrm{H}_{2} \mathrm{O}$ liquid aerosol mixture (e.g., Brock et al., 1995).

The amplitude of the annual cycle of background aerosol is small but variable with altitude. The upper boundary of the Junge layer peaks in winter, which is likely related to a weaker transport barrier between the tropical aerosol reservoir and the midlatitude stratospheric overworld during northern winter, when the wave-induced meridional mixing in the NH is most pronounced (Holton et al., 1990; Hitchman 


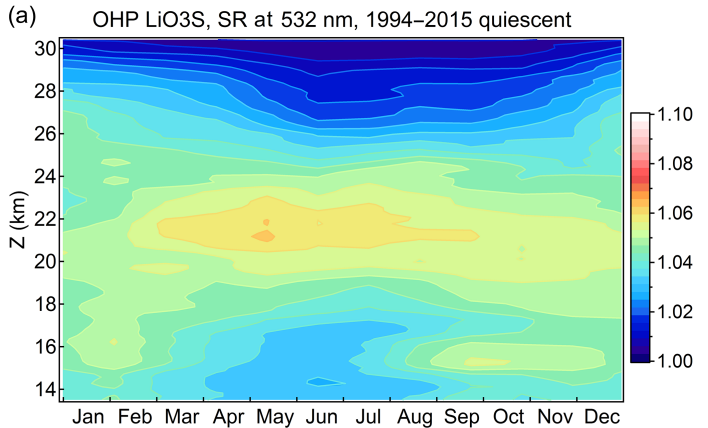

(b) CALIOP SR at $532 \mathrm{~nm}, 45^{\circ} \mathrm{N} \pm 2.5^{\circ}, 2006-2015$ quiescent

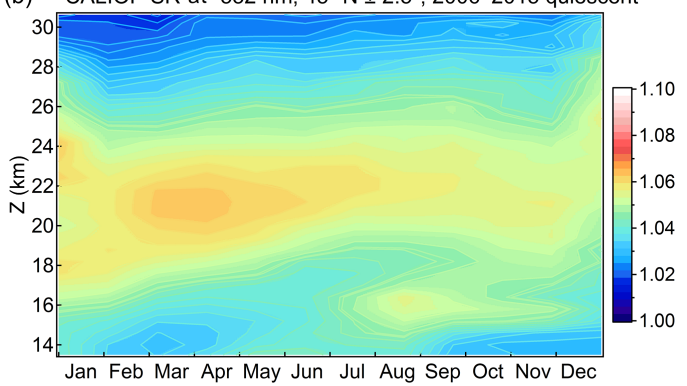

(c) $\quad \mathrm{MLS} \mathrm{H}_{2} \mathrm{O} 40-50^{\circ} \mathrm{N}$ zonal mean 2006-2015

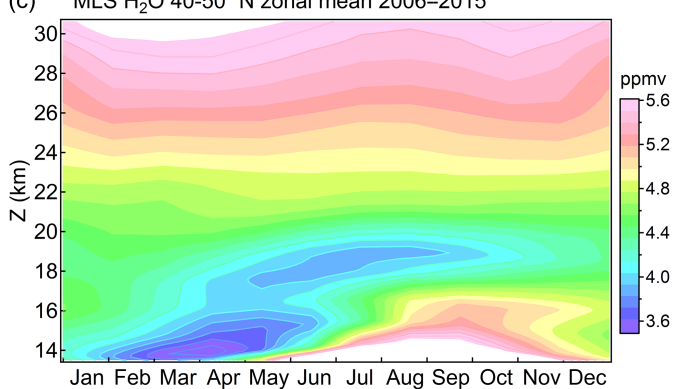

Figure 7. Climatological month-altitude sections of (a) SR from OHP LiO3S lidar for volcanically quiescent periods over the entire measurement time span (1994-2015); (b) zonal-mean SR at $45^{\circ} \mathrm{N} \pm 2.5^{\circ}$ from CALIOP, June 2006-September 2015 for volcanically quiescent periods (Table 2); (c) zonal mean water vapor at 40-50 N from MLS, June 2006-September 2015.

et al., 1994). Note that the meridional divergence of tropical air in the stratosphere is also modulated by the quasi-biennial oscillation (QBO), where the westerly shear phase favors the poleward transport during northern winter (Trepte and Hitchman, 1992).

In the middle layer (19-25 km), SR varies between 1.04 and 1.07 and shows a smooth maximum in spring. The lower layer - between 15 and $19 \mathrm{~km}$ - exhibits a more pronounced annual cycle, featuring a minimum in May at $16 \mathrm{~km}$, which propagates to $17 \mathrm{~km}$ by the end of August. In view of its altitude range and timing, this minimum can be attributed to the advection of convectively cleansed air from the TTL after the austral summer convective season (Vernier et al., 2011c) reaching midlatitudes in about 3 months as was concluded from Fig. 6. The late-spring minimum appears to be a robust feature captured by all other satellites (not shown), independently of the observation period. Starting from July, the clean air in the lower stratosphere (LS) is progressively replaced by aerosol-enriched air, presumably originating from the ATAL. The ATAL signature in OHP observations is bounded between 15 and $16 \mathrm{~km}$ altitude. Note that the initial inference on the extension of ATAL to OHP latitude is made on the basis of CALIOP time-latitude section in Fig. 6. The SR between 15 and $16 \mathrm{~km}$ reaches a maximum in September-October and reduces gradually over the course of the winter. Importantly, for any quiescent subperiod within the $22 \mathrm{yr}$ OHP record, the pattern is essentially the same.

Figure $7 \mathrm{~b}$ provides a satellite zonal-mean view of the nonvolcanic aerosol annual cycle observed by CALIOP since 2006. The month-altitude pattern of zonal-mean background aerosol revealed by CALIOP supports the climatology observed by the OHP lidar. The main features, namely the winter maximum of the Junge layer upper boundary, the spring maximum of SR in the middle layer $(19-25 \mathrm{~km})$ and the upward propagation of the late-spring clean feature are readily discernible in both OHP and CALIOP climatologies. The signature of ATAL at $15-16 \mathrm{~km}$ altitude is also well pronounced in the CALIOP section, which shows its maximum development in August as opposed to September according to OHP climatology. This may be due to zonal averaging for CALIOP, which incorporates the mid-Asian part of Asian monsoon, where ATAL is better developed in August (Fig. 2 in Vernier et al., 2015).

The OHP lidar and CALIOP capture well the main features of the background aerosol annual cycle in the lower mid-stratosphere and agree on them, whereas above $25 \mathrm{~km}$ CALIOP shows higher SR values compared to the OHP lidar and a somewhat less pronounced annual cycle. This may be due to a higher altitude of calibration for CALIOP retrieval and the use of different atmospheric models for deriving molecular backscatter (Sect. 2.3 and 3).

In the previous section we noted a relation between timelatitude variation in aerosol and water vapor in the lower stratosphere. Figure $7 \mathrm{c}$ shows the annual cycle of water vapor vertical profile, providing further evidence for this finding. Similarly to aerosol, the LS water vapor annual cycle exhibits the upward propagation of the late-spring minimum, followed by the maximum in autumn. As already pointed out on the basis of Fig. 6, both aerosol and water vapor in the midlatitude LS are modulated by the poleward transport of clean (dry) air from the deep tropics and aerosol-rich (wet) air from the Asian monsoon region. In fact, the annual cycle of extratropical water vapor bears an imprint of the tropical $\mathrm{H}_{2} \mathrm{O}$ "tape recorder" (Mote et al., 1996) lagged by the timescale of poleward transport from the TTL (e.g., Hoor et al., 2010). The same applies effectively to background aerosol, leading to similar month-altitude patterns of aerosol and water, as Fig. 7 suggests. 
(a) OHP AOD change since 1998

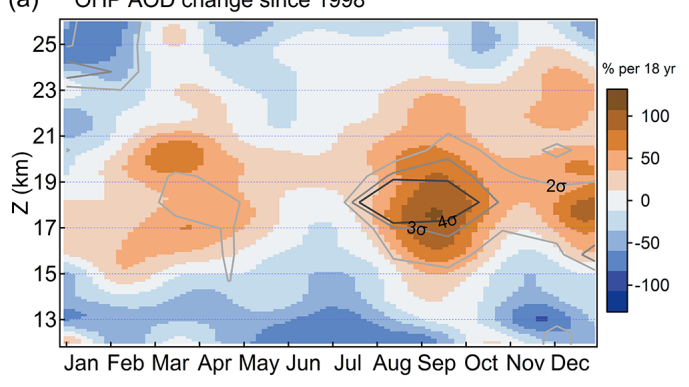

(b)

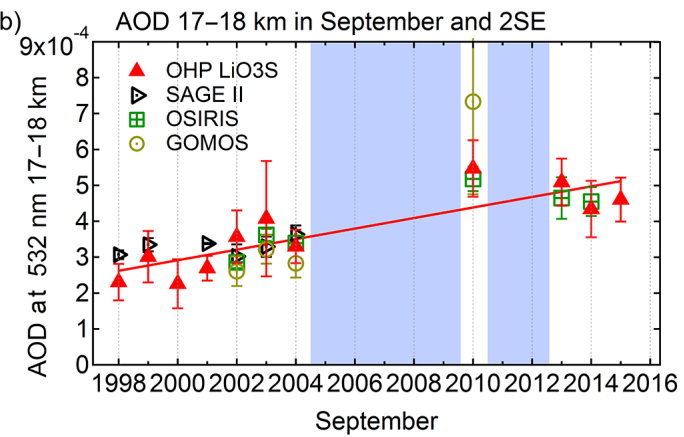

Figure 8. (a) Monthly averaged $1 \mathrm{~km}$ AOD change since 1998 from the OHP LiO3S lidar based on the observations during volcanically unperturbed periods. Statistically significant changes above the $95 \%$ confidence interval are encircled by grey-scaled contours. (b) Evolution of the AOD in the 17-18 km layer in September from the OHP LiO3S lidar and satellite observations above the western Mediterranean. Error bars denote 2 times the standard error. Shaded areas indicate the volcanically perturbed periods.

\subsection{Long-term change in stratospheric aerosol burden}

The detection of the long-term change in nonvolcanic component of stratospheric aerosol is complicated by frequent minor eruptions of stratovolcanoes, whose plumes may persist in the stratosphere for several years whilst decaying exponentially. A thorough analysis of the trends in the background stratospheric aerosol over 1971-2004 period (covering three quiescent periods) was carried out by Deshler et al. (2006), who concluded that there was an absence of longterm change. The 22-year stratospheric aerosol series provided here covers two quiescent periods: the reference 6-year long period 1997-2003 and a recent post-Nabro 2-year long period 2013-2014. This new-era quiescent period is characterized by the stabilization of the stratospheric aerosol load at a near-background level, rendering it suitable for comparison against the reference quiescent period. In this way, a positive change of $13.9 \pm 4.5 \%$ ( $2 \mathrm{SE}$ ) can be inferred by comparing average $\mathrm{sAOD}_{1730}$ values over the two periods. This estimate may be considered as an upper limit on the trend in nonvolcanic aerosol the NH midlatitude stratosphere but not without caution. First, there is the limited time span of the new quiescent period, 3 times shorter than the reference one. Second, there is a possible influence of eruptions with VEI 3, which may occasionally penetrate into the stratosphere (Carn et al., 2015; Mills et al., 2016). The second point, however, may also be true (although not detected or reported) for the reference quiescent period. Furthermore, the observations exploited here provide no indication of the influence of eruptions other than those listed above (Table 3 ).

If the change in stratospheric aerosol load is largely due to nonvolcanic processes, then the most likely source is the growing Asian emissions of aerosol precursors (Smith et al., 2011), transported into the lower stratosphere by the Asian monsoon (Randel et al., 2010). Indeed, the AOD of ATAL over the eastern Mediterranean, downwind of southeast Asia (Lawrence and Lelieveld, 2010), has increased three times since the late 1990s as inferred from SAGE II and CALIOP observations by Vernier et al. (2015). The OHP site is influenced by the Asian anticyclone and its composition, as shown above; hence, the change in ATAL AOD is expected to be reflected in OHP long-term series. However, given that the manifestation of the ATAL signal in OHP observations is limited to the autumn season and the lower stratosphere, the change in nonvolcanic aerosol should be evaluated with respect to the season and the layer.

Figure $8 \mathrm{a}$ displays vertically and seasonally resolved change in nonvolcanic sAOD over 18 years. The statistically significant increase by a factor of 2 in the LS is restricted to late summer and early fall; i.e., it is in phase with the Asian monsoon signatures detected in aerosol and water vapor. Note that little or no (statistically significant) increase is observed in other seasons, which suggests that the accumulation of volcanic aerosols (if any) is unlikely to be the reason for the positive trend. Indeed, zero change in the LS during late spring, i.e., when the tropical air reaches $\mathrm{NH}$ midlatitudes, rules out the effect of tropical plumes that are unaccounted for on the trend estimates.

Further insight into the long-term change in background aerosol is provided in Fig. 8b, showing the evolution of AOD in September within the altitude layer characterized by the maximum growth of AOD. Both the OHP lidar and satellites provide a clear indication of the increase in AOD with time. The value in 2010 , representing the post-Sarychev quiescent period, is slightly higher than the post-Nabro values; however, its contribution to the linear regression is limited to $12 \%$. The linear regression essentially rests upon the two quiescent periods separated in time: 1998-2004 and 20132015; hence, the trend value largely depends on the quantification of the aerosol level during the second period. This post-Nabro quiescent period was interrupted by the arrival of the Kelud plume at OHP latitude in early 2015. By September 2015 the Kelud plume is no longer observed at OHP: the value in September 2015 is not much different from the preKelud observations in 2013 and 2014, which suggests that the trend estimate is unaffected by the Kelud plume. Lidar 
observations at Tsukuba, $36^{\circ} \mathrm{N}$ (Sakai et al., 2016) do not show any indication of the presence of the Kelud plume in 2015.

\section{Discussion and summary}

Over the last 2 decades the NH stratosphere was perturbed by a series of minor volcanic eruptions, leaving strong but transient signals in the stratospheric aerosol load. A combination of concurrent local and global observations was used to carefully separate between volcanically perturbed and quiescent periods. The volcanic plumes and their meridional dispersion were detected using satellite observations, whereas the determination of a plume's lifetime was done by comparing OHP lidar measurements against the reference levels of background aerosol, corresponding to the 1997-2003 period. This approach suffers from the limited sensitivity of remotesensing techniques to low aerosol concentrations; however, it is the best that can be provided using the available observations.

The selection of quiescent periods is particularly challenging during the 2003-2012 period, characterized by frequent minor eruptions, occurring sometimes before the previous plume has fully decayed. However, the criteria applied allow the identification of several brief subperiods over 20032012, during which the stratospheric aerosol attains background levels. The quiescent periods, constituting a considerable fraction $(57 \%)$ of the 22-year span of OHP observations, yield a wealth of data for establishing a robust climatology of background aerosol at northern midlatitudes.

Analysis of nonvolcanic fraction of data suggests that the annual cycle of midlatitude background stratospheric aerosol is largely driven by remote (tropical) processes: convective cross-tropopause transport of clean air (Vernier et al., 2011c) during southern summer and polluted air from the Asian monsoon (Randel et al., 2010; Vernier et al., 2015; Yu et al., 2015) during northern summer, both followed by poleward transport. Although this interpretation appears consistent, alternative contributors should also be considered.

For example, the late-spring minimum in the lower stratosphere might be attributed to the release of clean air from within the Arctic vortex after its breakup or the gravitational settling of larger particles and their sinking through the tropopause folds (SPARC, 2006). However, the time-latitude variation in aerosol and water vapor unequivocally points to the poleward transport, thereby providing no support for these hypotheses. The clean air obviously originates from the TTL and whatever mechanisms are responsible (injections into the stratosphere or scavenging in tropopause clouds), the TTL cleansing is an important driver of the annual cycle of stratospheric aerosol on a global scale. It also appears that the cleansing process not only modulates the background aerosol but limits the lifetime of weak plumes residing mainly in the lower stratosphere.
The late-summer aerosol maximum might partly be due to midlatitude summertime forest fires and pyroconvection, whose stratospheric impact is recognized (Fromm et al., 2008, 2010). However, these events are rare and thus unlikely to contribute significantly to the multiyear averages. The coincidence between water vapor and nonvolcanic aerosol annual maxima in the $\mathrm{NH}$ midlatitude LS suggests that these air masses originate from the Asian monsoon, whose influence on the extratropical LS in late summer and early fall is well known (Vogel et al., 2014; Müller et al., 2016). Indeed, according to trajectory analyses by Garny and Randel (2016), $15 \%$ of the diabatic trajectories released at $360 \mathrm{~K}$ within the Asian anticyclone travel to the extratropical LS in 30 days or more, which is consistent with a 1-2 month lag of the aerosol and water vapor maxima with respect to the Asian monsoon season.

The influence of the Asian monsoon on the composition of the lower stratosphere at OHP - as suggested by our analysis - implies that the increase in ATAL AOD reported by Vernier et al. (2015) and Yu et al. (2015) should also be reflected in OHP lidar observations. Indeed, after the removal of volcanically perturbed data, we observe a doubling of LS partial AOD since 1998 in late summer and early fall, i.e., in phase with the ATAL signal detected at OHP.

Our trend estimate is consistent with that of Vernier et al. (2015), who found a tripling of the aerosol extinction anomaly (summer-to-winter ratio) above the eastern Mediterranean. It appears to be the case that the analysis of long-term change in nonvolcanic aerosol with respect to the season and altitude layer is the only way to obtain a credible trend estimate, in which the effect of volcanic plumes that are unaccounted for is minimized. In this way, the post-Nabro quiescent period, largely determining the observed trend, provides an accurate reference for the assessment of long-term change in nonvolcanic aerosol load.

The annual cycle of background aerosol is shown to reflect the meridional exchange processes, whereas its long-term evolution points to an increasing anthropogenic contribution to stratospheric aerosol budget. This effect appears very small compared to volcanic influence; however, it should not be ignored. Long-term continuous observations of stratospheric aerosol available from the NDACC lidar network are indispensable for following the evolution of stratospheric aerosol and detecting its human-induced change. The need for continuous ground-based observations becomes critical as there may be a lack in spaceborne aerosol measurements after CALIOP has ceased operation.

\section{Data availability}

All data sets and codes used to produce this study can be obtained by contacting Sergey Khaykin (sergey.khaykin@latmos.ipsl.fr). The OHP lidar data are available from the NDACC data base, ftp://ftp.cpc.ncep. 
noaa.gov/ndacc/station/ohp/ames/lidar/. The GOMOS AerGOM data can be obtained by contacting Christine Bingen (christine.bingen@aeronomie.be). The following satellite data used in this study are publically available: CALIPSO, https://eosweb.larc.nasa.gov/project/calipso/calipso_table;

SAGE II, https://eosweb.larc.nasa.gov/project/sage2/ sage2_table; OSIRIS, http://odin-osiris.usask.ca/; MLS, http://mls.jpl.nasa.gov/products/h2o_product.php.

Competing interests. The authors declare that they have no conflict of interest.

Acknowledgements. We thank the personnel of OHP for conducting lidar measurements. The work was done with the support of the French Institut National des Sciences de l'Univers (INSU) of the Centre National de la Recherche Scientifique (CNRS) and of the Centre National d'Etudes Spatiales (CNES). We thank Laurent Blanot (Acri ST) and Nickolay Kadygrov (IPSL) for their help with satellite data handling. OMPS LP Version 0.5 aerosol extinction coefficient data are produced by the LP processing team (https://ozoneaq.gsfc.nasa.gov/data/omps/). The AerGom project was financed by the European Space Agency (contract number 22022/OP/I-OL). Charles Robert's research was supported by a Marie Curie Career Integration Grant within the 7th European Community Framework Programme under grant agreement no. 293560, the European Space Agency within the Aerosol_CCI project of the Climate Change Initiative and the Belgian Space Science Office (BELSPO) through the Chercheur Supplémentaire programme. We also thank three anonymous reviewers for useful remarks that helped to improve the article.

Edited by: H. Maring

Reviewed by: three anonymous referees

\section{References}

Andersson, S., Martinsson, B., Vernier, J.-P., Friberg, J., Brenninkmeijer, C., Hermann, M., Velthoven, M., and Zahn, A.: Significant radiative impact of volcanic aerosol in the lowermost stratosphere, Nat. Commun., 6, 7692, doi:10.1038/ncomms8692, 2015.

Bertaux, J. L., Kyrölä, E., Fussen, D., Hauchecorne, A., Dalaudier, F., Sofieva, V., Tamminen, J., Vanhellemont, F., Fanton d'Andon, O., Barrot, G., Mangin, A., Blanot, L., Lebrun, J. C., Pérot, K., Fehr, T., Saavedra, L., Leppelmeier, G. W., and Fraisse, R.: Global ozone monitoring by occultation of stars: an overview of GOMOS measurements on ENVISAT, Atmos. Chem. Phys., 10, 12091-12148, doi:10.5194/acp-10-12091-2010, 2010.

Bourassa, A. E., Degenstein, D. A., Elash, B. J., and Llewellyn, E. J.: Evolution of the stratospheric aerosol enhancement following the eruptions of Okmok and Kasatochi: OdinOSIRIS measurements, J. Geophys. Res., 115, D00L03, doi:10.1029/2009jd013274, 2010.

Bourassa, A. E., Rieger, L. A., Lloyd, N. D., and Degenstein, D. A.: Odin-OSIRIS stratospheric aerosol data product and
SAGE III intercomparison, Atmos. Chem. Phys., 12, 605-614, doi:10.5194/acp-12-605-2012, 2012a.

Bourassa, A. E., Robock, A., Randel, W. J., Deshler, T., Rieger, L. A., Lloyd, N. D., Llewellyn, E. J., and Degenstein, D. A.: Large Volcanic Aerosol Load in the Stratosphere Linked to Asian Monsoon Transport, Science, 337, 78-81, 2012b.

Brock, C. A., Hamill, P., Wilson, J. C., Jonsson, H. H., and Chan, K. R.: Particle Formation in the Upper Tropical Troposphere a Source of Nuclei for the Stratospheric Aerosol, Science, 270, 1650-1653, 1995.

Carn, S. A., Yang, K., Prata, A. J., and Krotkov, N. A.: Extending the long-term record of volcanic $\mathrm{SO}_{2}$ emissions with the Ozone Mapping and Profiler Suite nadir mapper, Geophys. Res. Lett., 42, 925-932, doi:10.1002/2014GL062437, 2015.

DeLand, M., Bhartia, P. K., Xu, P., and Zhu, T.: OMPS Limb Profiler Aerosol Extinction Product AER675: Version 0.5 Data Release Notes, https://ozoneaq.gsfc.nasa.gov/media/docs/OMPS_ LP_AER675_V0.5_Release_Notes.pdf, 2016.

Deshler, T., Anderson-Sprecher, R., Jager, H., Barnes, J., Hofmann, D. J., Clemesha, B., Simonich, D., Osborn, M., Grainger, R. G., and Godin-Beekmann, S.: Trends in the nonvolcanic component of stratospheric aerosol over the period 1971-2004, J. Geophys. Res., 111, D01201, doi:10.1029/2005JD006089, 2006.

Chazette, P., David, C., Lefrère, J., Godin, S., Pelon, J., and Mégie, G.: Comparative lidar study of the optical, geometrical, and dynamical properties of stratospheric post-volcanic aerosols, following the eruption of El Chichon and Mount Pinatubo, J. Geophys. Res., 100, 23195-23207, 1995.

Godin-Beekmann, S., Porteneuve, J., and Garnier, A. : Systematic DIAL lidar monitoring of the stratospheric ozone vertical distribution at observatoire de haute-provence $\left(43.92^{\circ} \mathrm{N}, 5.71^{\circ} \mathrm{E}\right), \mathrm{J}$. Environ. Monitor., 5, 57-67, 2003.

Fairlie, T. D., Vernier, J.-P., Natarajan, M., and Bedka, K. M.: Dispersion of the Nabro volcanic plume and its relation to the Asian summer monsoon, Atmos. Chem. Phys., 14, 7045-7057, doi:10.5194/acp-14-7045-2014, 2014.

Fernald, F. G.: Analysis of atmospheric lidar observations: some comments, Appl. Opt., 23, 652-653, 1984.

Fiocco, G. and Grams, G.: Observations of the Aerosol Layer at 20 km by Optical Radar, J. Atmos. Sci., 21, 323-324, 1964.

Fromm, M., Shettle, E. P., Fricke, K. H., Ritter, C., Trickl, T., Giehl, H., Gerding, M., Barnes, J., O’Neill, M., Massie, S. T., Blum, U., McDermid, I. S., Leblanc, T., and Deshler, T.: The stratospheric impact of the Chisholm PyroCumulonimbus eruption: 2. Vertical profile perspective, J. Geophys. Res., 113, D08203, doi:10.1029/2007JD009147, 2008.

Fromm, M., Lindsey, D. T., Servranckx, R., Yue, G., Trickl, T., Sica, R., Doucet, P., and Godin-Beekmann, S.: The Untold Story of Pyrocumulonimbus, B. Am. Meterol. Soc., 91, 1193-1209, 2010.

Fyfe, J. C., von Salzen, K., Cole, J. N. S., Gillett, N. P., and Vernier, J.-P.: Surface response to stratospheric aerosol changes in a coupled atmosphere-ocean model, Geophys. Res. Lett., 40, 584588, doi:10.1002/grl.50156, 2013.

Garny, H. and Randel, W. J.: Transport pathways from the Asian monsoon anticyclone to the stratosphere, Atmos. Chem. Phys., 16, 2703-2718, doi:10.5194/acp-16-2703-2016, 2016.

Hauchecorne, A., Chanin, M.-L., Keckhut, P., and Nedeljkovic, D.: Lidar monitoring of the temperature in the middle and lower atmosphere, App. Phys. B, 55, 29-34, 1992. 
Haywood, J. M., Jones, A., Clarisse, L., Bourassa, A., Barnes, J., Telford, P., Bellouin, N., Boucher, O., Agnew, P., Clerbaux, C., Coheur, P., Degenstein, D., and Braesicke, P.: Observations of the eruption of the Sarychev volcano and simulations using the HadGEM2 climate model, J. Geophys. Res., 115, D21212, doi:10.1029/2010JD014447, 2010.

Hitchman, M. H., McKay, M., and Trepte, C. R.: A climatology of stratospheric aerosol, J. Geophys. Res., 99, 20689-20700, 1994.

Hoareau, C., Keckhut, P., Noel, V., Chepfer, H., and Baray, J.L.: A decadal cirrus clouds climatology from ground-based and spaceborne lidars above the south of France $\left(43.9^{\circ} \mathrm{N}-5.7^{\circ} \mathrm{E}\right)$, Atmos. Chem. Phys., 13, 6951-6963, doi:10.5194/acp-13-69512013, 2013.

Hofmann, D., Barnes, J., O’Neill, M., Trudeau, M., and Neely, R.: Increase in background stratospheric aerosol observed with lidar at Mauna Loa Observatory and Boulder, Colorado, Geophys. Res. Lett., 36, L15808, doi:10.1029/2009GL039008, 2009.

Holton, J. R., Haynes, P. H., McIntyre, M. E., Douglass, A. R., Rood, R. B., and Pfister, L.: Stratosphere-Troposphere Exchange, Rev. Geophys., 33, 403-439, 1995.

Hoor, P., Wernli, H., Hegglin, M. I., and Bönisch, H.: Transport timescales and tracer properties in the extratropical UTLS, Atmos. Chem. Phys., 10, 7929-7944, doi:10.5194/acp-10-79292010, 2010.

Jaross, G., Bhartia, P. K., Chen, G., Kowitt, M., Haken, M., Chen, Z., Xu, P., Warner, J., and Kelly, T.: OMPS Limb Profiler instrument performance assessment, J. Geophys. Res. Atmos., 119, 4399-4412, doi:10.1002/2013JD020482, 2014.

Jäger, H.: Long-term record of lidar observations of the stratospheric aerosol layer at Garmisch-Partenkirchen, J. Geophys. Res., 110, D08106, doi:10.1029/2004JD005506, 2005.

Jäger, H. and Deshler, T.: Lidar backscatter to extinction, mass and area conversions for stratospheric aerosols based on midlatitude balloon-borne size distribution measurements, Geophys. Res. Lett., 29, 1929, doi:10.1029/2002GL015609, 2002.

Jäger, H. and Deshler, T.: Correction to "Lidar backscatter to extinction, mass and area conversions for stratospheric aerosols based on midlatitude balloonborne size distribution measurements", Geophys. Res. Lett., 30, 1382, doi:10.1029/2003GL017189, 2003

Jégou, F., Berthet, G., Brogniez, C., Renard, J.-B., François, P., Haywood, J. M., Jones, A., Bourgeois, Q., Lurton, T., Auriol, F., Godin-Beekmann, S., Guimbaud, C., Krysztofiak, G., Gaubicher, B., Chartier, M., Clarisse, L., Clerbaux, C., Balois, J. Y., Verwaerde, C., and Daugeron, D.: Stratospheric aerosols from the Sarychev volcano eruption in the 2009 Arctic summer, Atmos. Chem. Phys., 13, 6533-6552, doi:10.5194/acp-13-6533-2013, 2013.

Junge, C. E., Chagnon, C. W., and Manson, J. E.: A Worldwide Stratospheric Aerosol Layer, Science, 133, 1478-1479, doi:10.1126/science.133.3463.1478-a, 1961.

Keckhut, P., Hauchecorne, A., Bekki, S., Colette, A., David, C., and Jumelet, J.: Indications of thin cirrus clouds in the stratosphere at mid-latitudes, Atmos. Chem. Phys., 5, 3407-3414, doi:10.5194/acp-5-3407-2005, 2005.

Klett, J. D.: Lidar inversion with variable backscatter/extinction ratios, Appl. Opt., 24, 1638-1643, 1985.

Kremser, S., Thomason, L. W., von Hobe, M., Hermann, M., Deshler, T., Timmreck, C., Toohey, M., Stenke, A., Schwarz, J. P.,
Weigel, R., Fueglistaler, S., Prata, V., Vernier, J.-P., Schlager, H., Barnes, J. E., Antuña-Marrero, J.-C., Fairlie, D., Palm, M., Mahieu, E., Notholt, J., Rex, M., Bingen, C., Vanhellemont, F., Bourassa, A., Plane, J. M. C., Klocke, D., Carn, S. A., Clarisse, L., Trickl, T., Neely, R., James, A. D., Rieger, L., Wilson, J. C., and Meland, B.: Stratospheric aerosol - Observations, processes, and impact on climate, Rev. Geophys., 54, 278-335, doi:10.1002/2015RG000511, 2016.

Kristiansen, N. I., Prata, A. J., Stohl, A., and Carn, S. A.: Stratospheric volcanic ash emissions from the 13 February 2014 Kelut eruption, Geophys. Res. Lett., 42, 588-596, doi:10.1002/2014GL062307, 2015.

Lawrence, M. G. and Lelieveld, J.: Atmospheric pollutant outflow from southern Asia: a review, Atmos. Chem. Phys., 10, 11017 11096, doi:10.5194/acp-10-11017-2010, 2010.

Livesey, N. J., Read, W. G., Wagner, P. A., Froidevaux, L., Lambert, A., Manney, G. L., Millán-Valle, L. F., Pumphrey, H. C., Santee, M. L., Schwartz, M. J., Wang, S., Fuller, R. A., Jarnot, R. F., Knosp, B. W., and Martinez, E.: Version 4.2x Level 2 data quality and description document, Tech. Rep. JPL D-33509, NASA Jet Propulsion Laboratory, version 4.2x-1.0, 2015.

McLinden, C., Bourassa, A., Brohede, S., Cooper, M., Degenstein, D., Evans, W., Gattinger, R., Haley, C., Llewellyn, E., Lloyd, N., Loewen, P., Martin, R., McConnell, J., McDade, I., Murtagh, D., Rieger, L., von Savigny, C., Sheese, P., Sioris, C., Solheim, B., and Strong, K.: OSIRIS: A decade of scattered light, Bull. Am. Meteorol. Soc., 93, 1845-1863, 2012.

Mills, M. J., Schmidt, A., Easter, R., Solomon, S., Kinnison, D. E., Ghan, S. J., Neely, R. R. III, Marsh, D. R., Conley, A., Bardeen, C. G., and Gettleman, A.: Global volcanic aerosol properties derived from emissions, 1990-2014, using CESM1(WACCM), J. Geophys. Res. Atmos., 121, 2332-2348, doi:10.1002/2015JD024290, 2016.

Mote, P., Rosenlof, K. H., Holton, J. R., Harwood, R. S., and Waters, J. W.: An atmospheric tape recorder: The imprint of tropical tropopause temperatures on stratospheric warter vapor, J. Geophys. Res., 101, 3989-4006, 1996.

Müller, S., Hoor, P., Bozem, H., Gute, E., Vogel, B., Zahn, A., Bönisch, H., Keber, T., Krämer, M., Rolf, C., Riese, M., Schlager, H., and Engel, A.: Impact of the Asian monsoon on the extratropical lower stratosphere: trace gas observations during TACTS over Europe 2012, Atmos. Chem. Phys., 16, 10573-10589, doi:10.5194/acp-16-10573-2016, 2016.

Park, M., Randel, W. J., Gettelman, A., Massie, S. T., and Jiang, J. H.: Transport above the Asian summer monsoon anticyclone inferred from Aura Microwave Limb Sounder tracers, J. Geophys. Res., 112, D16309, doi:10.1029/2006JD008294, 2007.

Prata, A. J., Carn, S. A., Stohl, A., and Kerkmann, J.: Long range transport and fate of a stratospheric volcanic cloud from Soufrière Hills volcano, Montserrat, Atmos. Chem. Phys., 7, 5093-5103, doi:10.5194/acp-7-5093-2007, 2007.

Randel, W. J., Park, M., Emmons, L., Kinnison, D., Bernath, P., Walker, K. A., Boone, C., and Pumphrey, H.: Asian monsoon transport of pollution to the stratosphere, Science, 328, 611-613, doi:10.1126/science.1182274, 2010.

Ridley, D. A., Solomon, S., Barnes, J. E., Burlakov, V. D., Deshler, T., Dolgii, S. I., Herber, A. B., Nagai, T., Neely, R. R., Nevzorov, A. V., Ritter, C., Sakai, T., Santer, B. D., Sato, M., Schmidt, A., Uchino, O., and Vernier, J. P.: Total volcanic stratospheric aerosol 
optical depths and implications for global climate change, Geophys. Res. Lett., 41, 7763-7769, doi:10.1002/2014GL061541, 2014.

Russell, P. B. and McCormick, M. P.: SAGE II aerosol data validation and initial data use: An introduction and overview, J. Geophys. Res., 94, 8335-8338, doi:10.1029/JD094iD06p08335, 1989.

Sakai, T., Uchino, O., Nagai, N., Liley, B., Morino, I., and Fujimoto, T.: Long-term variation of stratospheric aerosols observed with lidars over Tsukuba, Japan, from 1982 and Lauder, New Zealand, from 1992 to 2015, J. Geophys. Res. Atmos., 121, 10283-10293, doi:10.1002/2016JD025132, 2016.

Santer, B. D., Bonfils, C., Painter, J. F., Zelinka, M. D., Mears, C., Solomon, S., Schmidt, G. A., Fyfe, J. C., Cole, J. N. S., Nazarenko, L., Taylor, K. E., and Wentz, F. J.: Volcanic contribution to decadal changes in tropospheric temperature, Nat. Geosci., 7, 185-189, doi:10.1038/ngeo2098, 2014.

Santer, B. D., Solomon, S., Bonfils, C., Zelinka, M. D., Painter, J. F., Beltran, F., Fyve J. C., Johanesson, G., Mears C., Ridley, D. A., Vernier, J.-P., and Wentz, F. J.: Observed multivariable signals of late 20th and early 21 st century volcanic activity, Geophys. Res. Lett., 42, 500-509, doi:10.1002/2014GL062366, 2015.

Sawamura, P., Vernier, J. P., Barnes, J. E., Berkoff, T. A., Welton, E. J., Alados-Arboledas, L., Navas-Guzm'an, F., Pappalardo, G., Mona, L., Madonna, F., Lange, D., Sicard, M., Godin-Beekmann, S., Payen, G., Wang, Z., Hu, S., Tripathi, S. N., CordobaJabonero, C., and Hoff, R. M.: Stratospheric AOD after the 2011 eruption of Nabro volcano measured by lidars over the Northern Hemisphere, Environ. Res. Lett., 7, 034013, doi:10.1088/17489326/7/3/034013, 2012.

Schwartz, M. J., Manney, G. L., Hegglin, M. I., Livesey, N. J., Santee, M. L., and Daffer, W. H.: Climatology and variability of trace gases in extratropical double-tropopause regions from MLS, HIRDLS and ACE-FTS measurements, J. Geophys. Res., 120, 843-867, doi:10.1002/2014JD021964, 2015.

Smith, S. J., van Aardenne, J., Klimont, Z., Andres, R. J., Volke, A., and Delgado Arias, S.: Anthropogenic sulfur dioxide emissions: 1850-2005, Atmos. Chem. Phys., 11, 1101-1116, doi:10.5194/acp-11-1101-2011, 2011.

Solomon, S., Daniel, J. S., Neely, R. R., Vernier, J.-P., Dutton, E. G., and Thomason, L. W.: The Persistently Variable "Background" Stratospheric Aerosol Layer and Global Climate Change, Science, 333, 866-870, doi:10.1126/science.1206027, 2011.

SPARC/ASAP: WMO/SPARC Scientific Assessment of Stratospheric Aerosol Properties (ASAP), WCRP-124 WMO/TD- No. 1295, SPARC Report No. 4, edited by: Thomason, L. and Peter, T., WMO, 2006.

Thomason, L. W., Burton, S. P., Luo, B.-P., and Peter, T.: SAGE II measurements of stratospheric aerosol properties at non-volcanic levels, Atmos. Chem. Phys., 8, 983-995, doi:10.5194/acp-8-9832008, 2008.

Thomason, L. W. and Vernier, J.-P.: Improved SAGE II cloud/aerosol categorization and observations of the Asian tropopause aerosol layer: 1989-2005, Atmos. Chem. Phys., 13, 4605-4616, doi:10.5194/acp-13-4605-2013, 2013.

Trepte, C. R. and Hitchman, M. H.: Tropical stratospheric circulation deduced from satellite aerosol data, Nature, 355, 626-628, 1992.
Trickl, T., Giehl, H., Jäger, H., and Vogelmann, H.: 35 yr of stratospheric aerosol measurements at Garmisch-Partenkirchen: from Fuego to Eyjafjallajökull, and beyond, Atmos. Chem. Phys., 13, 5205-5225, doi:10.5194/acp-13-5205-2013, 2013.

Vanhellemont, F., Fussen, D., Mateshvili, N., Tétard, C., Bingen, C., Dekemper, E., Loodts, N., Kyrölä, E., Sofieva, V., Tamminen, J., Hauchecorne, A., Bertaux, J.-L., Dalaudier, F., Blanot, L., Fanton d'Andon, O., Barrot, G., Guirlet, M., Fehr, T., and Saavedra, L.: Optical extinction by upper tropospheric/stratospheric aerosols and clouds: GOMOS observations for the period 20022008, Atmos. Chem. Phys., 10, 7997-8009, doi:10.5194/acp-107997-2010, 2010.

Vanhellemont, F., Mateshvili, N., Blanot, L., Robert, C. É., Bingen, C., Sofieva, V., Dalaudier, F., Tétard, C., Fussen, D., Dekemper, E., Kyrölä, E., Laine, M., Tamminen, J., and Zehner, C.: AerGOM, an improved algorithm for stratospheric aerosol extinction retrieval from GOMOS observations - Part 1: Algorithm description, Atmos. Meas. Tech., 9, 4687-4700, doi:10.5194/amt9-4687-2016, 2016.

Vogel, B., Günther, G., Müller, R., Grooß, J.-U., Hoor, P., Krämer, M., Müller, S., Zahn, A., and Riese, M.: Fast transport from Southeast Asia boundary layer sources to northern Europe: rapid uplift in typhoons and eastward eddy shedding of the Asian monsoon anticyclone, Atmos. Chem. Phys., 14, 12745-12762, doi:10.5194/acp-14-12745-2014, 2014.

Vernier, J. P., Pommereau, J. P., Garnier, A., Pelon, J., Larsen, N., Nielsen, J., Christensen, T., Cairo, F., Thomason, L. W., Leblanc, T., and McDermid, I. S.: The tropical stratospheric aerosol layer from CALIPSO lidar observations, J. Geophys. Res., 114, D00H10, doi:10.1029/2009JD011946, 2009.

Vernier, J. P., Thomason, L. W., Pommereau, J. P., Bourassa, A., Pelon, J., Garnier, A., Hauchecorne, A., Blanot, L., Trepte, C., Degenstein, D., and Vargas, F.: Major influence of tropical volcanic eruptions on the stratospheric aerosol layer during the last decade, Geophys. Res. Lett., 38, L12807, doi:10.1029/2011GL047563, 2011a.

Vernier, J.-P., Thomason, L. W., and Kar, J.: CALIPSO detection of an Asian tropopause aerosol layer, Geophys. Res. Lett., 38, L07804, doi:10.1029/2010GL046614, 2011b.

Vernier, J.-P., Pommereau, J.-P., Thomason, L. W., Pelon, J., Garnier, A., Deshler, T., Jumelet, J., and Nielsen, J. K.: Overshooting of clean tropospheric air in the tropical lower stratosphere as seen by the CALIPSO lidar, Atmos. Chem. Phys., 11, 96839696, doi:10.5194/acp-11-9683-2011, 2011c.

Vernier, J.-P., Thomason, L., Fairlie, T. D., Minnis, P., Palikonda, R., and Bedka, K. M.: Comment on "Large volcanic aerosol load in the stratosphere linked to Asian monsoon transport", Science, 339, 6120, doi:10.1126/science.1227817, 2013.

Vernier, J. P., Fairlie, T. D., Natarajan, M., Wienhold, F. G., Bian, J., Martinsson, B. G., Crumeyrolle, S., Thomason, L. W., and Bedka, K. M.: Increase in upper tropospheric and lower stratospheric aerosol levels and its potential connection with Asian pollution, J. Geophys. Res.-Atmos., 120, 1608-1619, doi:10.1002/2014JD022372, 2015.

Waters, J. W., Froidevaux, L., Harwood, R. S., Jarnot, R. F., Pickett, H. M., Read, W. G., and Holden, J. R.: The earth observing system microwave limb sounder (EOS MLS) on the Aura satellite, IEEE T. Geosci. Remote, 44, 1075-1092, 2006. 
Winker, D. M., Pelon, J., Coakley Jr., J. A., Ackerman, S. A., Charlson, R. J., Colarco, P. R., Flamant, P., Fu, Q., Hoff, R., Kittaka, C., Kubar, T. L., LeTreut, H., McCormick, M. P., Megie, G., Poole, L., Powell, K., Trepte, C., Vaughan, M. A., and Wielicki, B. A.: The CALIPSO Mission: A Global 3D View Of Aerosols And Clouds, B. Am. Meteorol. Soc., 91, 1211-1229, doi:10.1175/2010BAMS3009.1, 2010.
Yu, P., Toon, O. B., Neely, R. R., Martinsson, B. G., and Brenninkmeijer, C. A. M.: Composition and Physical Properties of the Asian Tropopause Aerosol Layer and the North American Tropospheric Aerosol Layer, Geophys. Res. Lett., 42, 2540-2546, doi:10.1002/2015GL063181, 2015. 